\title{
Narrative Review of the Literature on Adherence to Disease- Modifying Therapies Among Patients with Multiple Sclerosis
}

\author{
Joseph Menzin, PhD; Christina Caon, RN, MSN, NP-C; Christine Nichols, BA; \\ Leigh Ann White, PhD; Mark Friedman, MD; and Michael W. Pill, PharmD
}

\begin{abstract}
While no curative treatment exists for multiple sclerosis (MS), several disease-modifying therapies (DMTs) have been developed to reduce relapse rates, slow disability progression, and modify the overall disease course. However, because of the chronic nature of the disease, long-term therapy adherence can be challenging for some patients with MS. Low adherence to DMTs has been shown to be associated with higher rates of disease relapses and progression as well as with an increase in medical resource utilization. As new MS treatments are developed, a comprehensive understanding of current adherence rates and the impact of adherence on clinical and economic outcomes is of particular interest. Our objective was to conduct a review of the published literature to evaluate rates of adherence to DMTs in MS and the impact of adherence on both clinical and economic outcomes from the patient and payer perspectives.

Systematic literature searches were conducted using MEDLINE, EMBASE, and the Cochrane Central Register for Controlled Trials. Studies were limited to those completed on human subjects, written in the English language, and published between May 1, 2001, and May 1, 2011. Additional inclusion criteria required that studies involve a population of patients with MS, utilize the administration of DMTs, and report a measurement of adherence. Studies reporting persistence measures (e.g., treatment discontinuation rates) or rates of switching between DMTs (with no other measure of adherence reported) were excluded if they did not also assess adherence.

Among the 24 studies meeting inclusion criteria, adherence to DMTs ranged from $41 \%$ to $88 \%$. Weighted mean adherence rates were higher for intramuscular (IM) interferon beta-1a (IFN $\beta$-1a) administered once a week $(69.4 \%)$, and subcutaneous (SC) IFN $\beta-1$ a administered every other day $(63.8 \%)$ than for SC IFN $\beta-1 \mathrm{~b}$ administered 3 times a week $(58.4 \%)$ and glatiramer acetate administered daily $(56.8 \%)$. There was a numerically greater risk of MS relapse or disease progression among patients nonadherent to therapy versus adherent patients, with findings statistically significant in 2 of 4 studies. Additionally, 2 studies showed statistically significant reductions in inpatient or emergency room utilization and total MS-related medical costs among patients adherent to therapy compared with nonadherent patients. Higher patient out-of-pocket copayments and coinsurance were significantly associated with lower adherence to DMTs, while the use of interventional or disease therapy management programs were associated with improved adherence.

Lack of medication adherence remains a problem among patients with MS. Improvements in adherence have the potential to improve patient and payer burden in terms of improved clinical outcomes and lower nonpharmacy medical resource utilization.
\end{abstract}

J Manag Care Pharm. 2013;19(1-a):S24-S40

Copyright $\odot 2013$, Academy of Managed Care Pharmacy. All rights reserved.

\section{Summary Points Presented in this Article}

- Because of the chronic nature of multiple sclerosis (MS), long-term adherence to disease-modifying therapies (DMTs) can be challenging.

- Common barriers to adherence include forgetting to inject; a patient-perceived lack of efficacy; anxiety over injections or selfinjecting; and adverse effects, including injection site reactions, flu-like symptoms, and fatigue.

- Recent reviews have cited that $60 \%$ to $76 \%$ of patients are adherent to either interferon beta-la (IFN $\beta$-la) or glatiramer acetate (GA) therapies. This review identified 24 studies of adherence to injectable DMTs (including once-weekly intramuscular [IM] and 3 times a week subcutaneous [SC] IFN $\beta$-la, every other day SC IFN $\beta-1 b$, and daily GA), with adherence rates ranging between $41 \%$ and $88 \%$.

- Adherence was generally higher in studies with prospective rather than retrospective study designs. Weighted mean adherence rates were higher for IM IFN $\beta$-la (69.4\%) and SC IFN $\beta$-la (63.8\%) than for SC IFN $\beta-1 b$ (58.4\%) and GA (56.8\%).

- Selected studies showed that patients who were more adherent to therapy had a lower risk of MS relapse. One study showed patients adherent to therapy had a lower risk of MS-related hospitalizations and lower total MS-related costs (excluding pharmacy costs).

$\mathrm{M}$ ultiple sclerosis (MS) is a chronic, recurrent inflammatory disease of the white and grey matter of the central nervous system (CNS), affecting approximately 400,000 persons in the United States and 2.5 million people worldwide. ${ }^{1}$ MS is characterized by inflammatory attacks on CNS myelin, thought to be autoimmune in nature, which result in a variety of symptoms such as blurred vision, walking and coordination problems, bladder or bowel dysfunction, numbness, and cognitive impairment. Relapsingremitting MS (RRMS) is characterized by clearly defined attacks, or relapses, of worsening neurological function with periods of partial to complete recovery between each attack. ${ }^{2}$ This form of the disease comprises approximately $85 \%$ of presenting MS diagnoses. ${ }^{1}$

While no curative treatment exists for RRMS, several disease-modifying therapies (DMTs) have been developed to reduce relapse rates, slow disability progression, and modify the overall disease course. ${ }^{3}$ The U.S. Food and Drug Administration (FDA) has approved several DMTs (Table 1), ${ }^{4-12}$ including once-weekly intramuscular (IM) interferon beta-la (IFN $\beta-1 \mathrm{a}$; Avonex), 3 times a week subcutaneous (SC) IFN $\beta-1 \mathrm{a}$ (Rebif), alternating daily IFN $\beta-1 b$ (Betaseron, Extavia), oncedaily SC glatiramer acetate (GA; Copaxone), once-monthly intravenous (IV) natalizumab (Tysabri), and 4 times yearly IV 


\section{TABLE 1 FDA-Approved Drugs for Multiple Sclerosis}

Drug and Date of

FDA Approval

Interferon beta-lb SC (Betaseron) ${ }^{4}$

July 1993

Interferon beta-la IM

$(\text { Avonex })^{5}$

May 1996
Dosing and Administration ${ }^{\mathrm{a}}$

"Recommended dose is $0.25 \mathrm{mg}$ injected SC every other day. Generally, start at $0.0625 \mathrm{mg}(0.25 \mathrm{~mL}) \mathrm{SC}$ every other day, and increase over a 6 -week period to $0.25 \mathrm{mg}$ $(1 \mathrm{~mL})$ every other day."

"The recommended dosage is $30 \mathrm{mcg}$ injected IM once a week. To reduce the incidence and severity of flu-like symptoms that may occur when initiating Interferon betala IM therapy at a dose of $30 \mathrm{mcg}$, Interferon beta-la IM may be started at a dose of $7.5 \mathrm{mcg}$ and the dose may be increased by $7.5 \mathrm{mcg}$ each week for the next three weeks until the recommended dose of $30 \mathrm{mcg}$ is achieved. All Interferon beta-la IM dosage forms are single-use (injection of reconstituted solution, prefilled syringe, and prefilled autoinjector)."

Glatiramer acetate SC "For SC injection only; recommended dose is $20 \mathrm{mg} /$ day."

(Copaxone) $^{6}$

December 1996

Interferon beta-la SC

$\left(\right.$ Rebif) ${ }^{7}$

March 2002

"Dosages shown to be safe and effective are $22 \mathrm{mcg}$ and 44 mcg injected SC 3 times per week (tiw). IFN beta-la SC should be administered, if possible, at the same time (preferably in the late afternoon or evening) on the same 3 days (e.g., Monday, Wednesday, and Friday) at least 48 hours apart each week. Generally, patients should be started at $20 \%$ of the prescribed dose tiw and increased over a 4-week period to the targeted dose, either $22 \mathrm{mcg}$ or 44 mcg tiw."

\begin{tabular}{l|l}
\hline Natalizumab & "300 mg infused intravenously over approximately 1 hour,
\end{tabular}

(Tysabri) $^{8}$

November 2004;

reintroduced

July 2006

every 4 weeks. Do not give as an intravenous push or bolus. Natalizumab solution must be administered within 8 hours of preparation. Natalizumab is available only through a special restricted distribution program called the TOUCH Prescribing Program and must be administered only to patients enrolled in this program."

Interferon beta-1b SC $\quad$ "The recommended dose is $0.25 \mathrm{mg}$ injected SC every (Extavia) ${ }^{9}$

August 2009 other day. Generally, patients should be started at 0.0625 $\mathrm{mg}(0.25 \mathrm{~mL}) \mathrm{SC}$ every other day, and increased over a 6-week period to $0.25 \mathrm{mg}(1 \mathrm{~mL})$ every other day."

Dalfampridine

(Ampyra) 10

January 2010

Fingolimod

(Gilenya) 11

September 2010

Mitoxantrone

(Novantrone) $)^{12}$

January 2000
"Maximum recommended dose is $10 \mathrm{mg}$ twice daily

(approximately 12 hours apart) with or without food."

"The recommended dose is $0.5 \mathrm{mg}$ orally once daily, with or without food."

"The recommended dosage of NOVANTRONE is $12 \mathrm{mg} / \mathrm{m}^{2}$ given as a short (approximately 5 to 15 minutes) intravenous infusion every 3 months."
FDA-Approved Indications

"Treatment of relapsing forms of MS to reduce the frequency of clinical exacerbations. Patients with MS in whom efficacy has been demonstrated include patients who have experienced a first clinical episode and have MRI features consistent with MS."

"Treatment of patients with relapsing forms of MS to slow the accumulation of physical disability and decrease the frequency of clinical exacerbations. Patients with MS in whom efficacy has been demonstrated include patients who have experienced a first clinical episode and have MRI features consistent with MS."

"Reduction of the frequency of relapses in patients with RelapsingRemitting MS, including patients who have experienced a first clinical episode and have MRI features consistent with MS."

"Treatment of patients with relapsing forms of MS to decrease the frequency of clinical exacerbations and delay the accumulation of physical disability. Efficacy in chronic progressive MS has not been established."

"As monotherapy for the treatment of patients with relapsing forms of MS to delay the accumulation of physical disability and reduce the frequency of clinical exacerbations. Natalizumab is generally recommended for patients who have had an inadequate response to, or are unable to tolerate, an alternate MS therapy.'

"Treatment of relapsing forms of MS to reduce the frequency of clinical exacerbations. Patients with MS in whom efficacy has been demonstrated include patients who have experienced a first clinical episode and have MRI features consistent with MS."

"Indicated to improve walking in patients with MS. This was demonstrated by an increase in walking speed."

"Treatment of patients with relapsing forms of MS to reduce the frequency of clinical exacerbations and to delay the accumulation of physical disability."

"Reducing neurologic disability and/or the frequency of clinical relapses in patients with secondary (chronic) progressive, progressive relapsing, or worsening relapsing-remitting multiple sclerosis (i.e., patients whose neurologic status is significantly abnormal between relapses). NOVANTRONE is not indicated in the treatment of patients with primary progressive multiple sclerosis."

anformation for column 2 comes from the prescribing information for each drug, which is referenced in column 1.

FDA =U.S. Food and Drug Administration; IFN=interferon; $I M=$ intramuscular; $m^{2}=$ meters squared; $m c g=$ microgram; $m g=m i l l i g r a m ; m L=m i l l i l i t e r ; M R I=m a g n e t i c$ resonance imaging; $\mathrm{MS}=$ multiple sclerosis; $S \mathrm{C}=$ subcutaneous; $\mathrm{TOUCH}=$ Tysabri Outreach: Unified Commitment to Health.

mitoxantrone (Novantrone). ${ }^{13}$ All injectable DMTs have been approved to reduce the frequency of clinical relapses, with IM IFN $\beta-1 \mathrm{a}$, SC IFN $\beta-1 \mathrm{a}$, and natalizumab also indicated by the FDA to slow disability progression; IM IFN $\beta-1 a$, SC IFN $\beta-1 b$, and GA are also indicated in patients who have experienced a first clinical episode and have magnetic resonance imaging (MRI) features consistent with MS (Table 1). ${ }^{3}$ In 2010, oral fingolimod (Gilenya) was approved by the FDA to reduce the frequency of clinical relapses and delay the accumulation of physical disability in patients with RRMS. ${ }^{3}$ 


\section{FIGURE 1 Literature Review Flowchart ${ }^{\mathrm{a}}$}

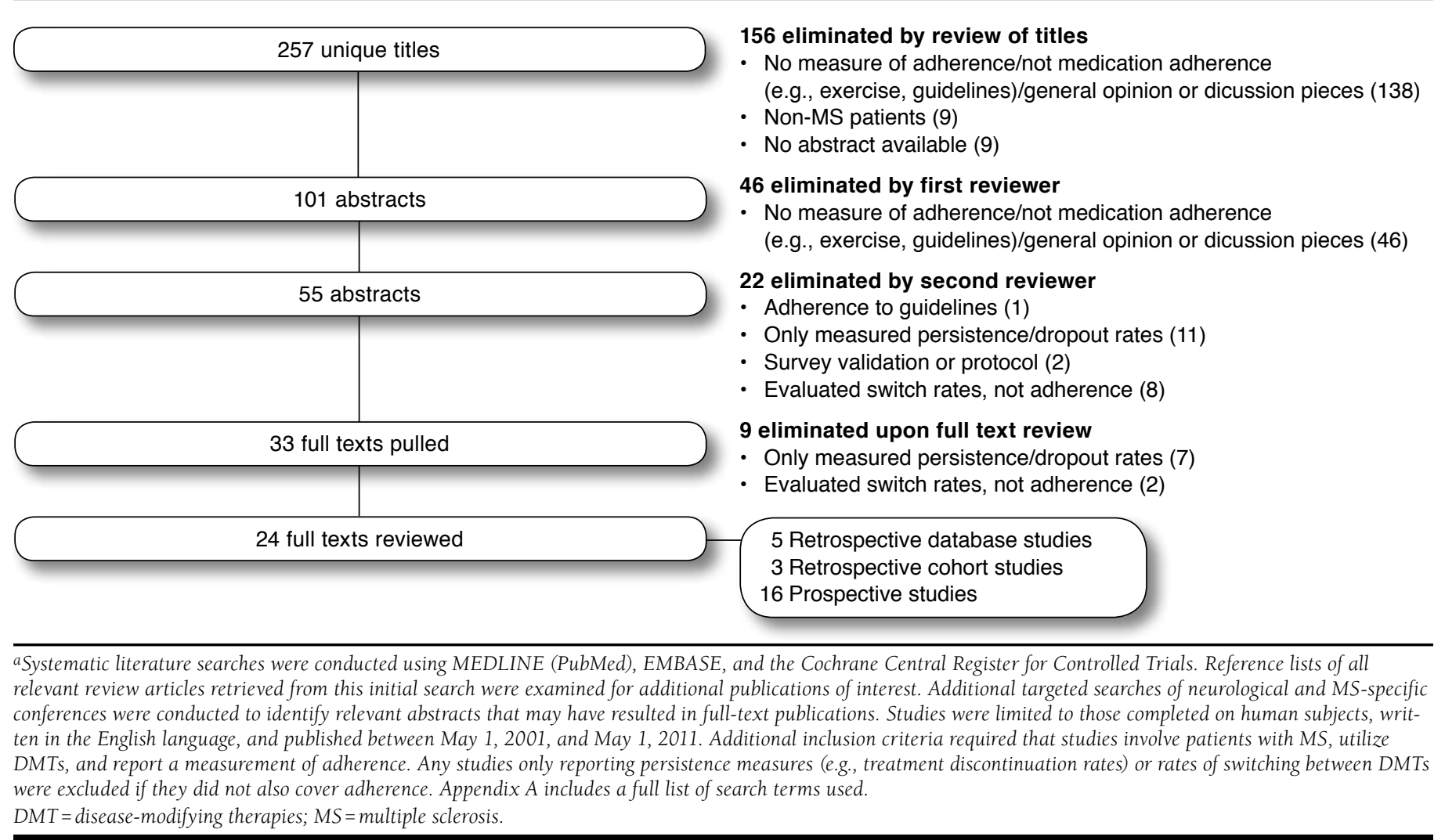

Because of the chronic nature of the disease, long-term therapy adherence can be challenging for some patients with MS. ${ }^{14}$ Common barriers to adherence with injectable DMTs include forgetting to inject; patient-perceived lack of efficacy; injection anxiety; and adverse effects, including injection-site reactions, flu-like symptoms, and fatigue. ${ }^{15}$ Nonadherence to DMTs has been shown to have a negative impact on clinical outcomes, including higher rates of relapse and disease progression, ${ }^{16,17}$ as well as an increase in hospital resource utilization. ${ }^{18}$ However, according the the European Multiple Sclerosis Therapy Consensus Group (MSTCG) guidelines, patients may discontinue treatment with DMTs after 3 years, if there is no evidence of relapse and/or progression. ${ }^{19}$

This review focuses on patient adherence to therapy, a distinct concept from persistence to therapy. As defined by the International Society for Pharmacoeconomics and Outcomes Research (ISPOR) Medication Compliance and Persistence Special Interest Group, adherence is the percentage of doses taken as prescribed, over a set time period for analysis (either from the first to last medication dispensing date or for a fixed follow-up time frame). ${ }^{20}$ Persistence is defined as the total number of days taking medication over a set time period.
Medication persistence is commonly reported in the MS literature as the percentage of patients discontinuing therapy or with a significant gap in therapy (e.g., at least more than a 30-day gap). ${ }^{21-23}$ We chose to focus on adherence rates in this review, as this not only encompasses treatment discontinuations, but also the actual patient experience while on treatment in terms of the number of doses taken as prescribed. This gives a fuller picture of the proportion of patients who not only are able to actively remain on therapy, but who also are able to follow a complex and often burdensome treatment regimen.

As new treatments are developed for MS, a comprehensive understanding of current adherence rates and the impact of adherence on clinical and economic outcomes will be beneficial in clinical decision making and overall disease management. In addition to the traditional factors of clinical efficacy, safety, and costs, differences in patient adherence to therapies in MS may be important in formulary decision making. Our objective was to conduct a thorough review of the literature to evaluate various definitions and rates of adherence to MS DMTs, the impact of adherence on clinical outcomes and resource use and costs, and the implications of adherence to DMTs for both patients and payers. 


\section{Methods}

Literature search strategies and data extraction were followed as outlined in the Cochrane Collaboration Handbook of Systematic Reviews for Interventions. ${ }^{24}$ This included pre-specifying a search strategy and search terms; use of MEDLINE, EMBASE, and the Cochrane library; and use of 2 reviewers. Two reviewers created search terms; 1 reviewer scanned preliminary titles returned in the search results; 1 reviewer performed supplementary searches using author names and conference abstracts; and 2 reviewers evaluated the full list of potentially relevant abstracts to select studies relevant for full-text review.

Systematic literature searches were conducted using MEDLINE (PubMed), EMBASE, and the Cochrane Central Register for Controlled Trials, using the same search terms in all databases, as summarized in Appendix A. In order to cross-check findings from these searches, reference lists of all relevant review articles retrieved were examined to identify any additional publications not returned in the database searches. Additionally, targeted searches of neurological and MS-specific conferences were conducted to identify relevant abstracts that may have resulted in full-text publications not already identified through the database searches described above. Conferences included the American Academy of Neurology (AAN), the European Committee for Treatment and Research in Multiple Sclerosis (ECTRIMS), and the European Federation of Neurological Societies (EFNS). PubMed and the Internet were used to identify any full-text publications resulting from relevant abstracts.

Studies were limited to those completed on human subjects, written in the English language, and published between May 1, 2001, and May 1, 2011. Additional inclusion criteria required that studies involve a population of patients with MS, utilize the administration of DMTs, and report a measurement of adherence. Studies reporting persistence measures (e.g., treatment discontinuation rates) or rates of switching between DMTs (with no other measure of adherence reported) were excluded if they did not also cover adherence. These persistence-only articles were not evaluated in this review, since we were interested in assessing the full patient experience while on therapy (i.e., dosing taken as prescribed).

A total of 257 unique titles was initially identified through the search methodology previously outlined, of which 101 abstracts were reviewed in more detail; 33 full texts were pulled; and 24 full texts summarized. Main exclusionary criteria included studies with no measures of medication adherence reported (i.e., persistence only, adherence to guidelines) and general opinion or discussion pieces with no adherence rates reported. Figure 1 provides a complete flowchart of the study selection methodology. For each study meeting our selection criteria, the following data were abstracted: study type and objective, DMT type(s) evaluated, patient population, study period/duration of follow-up, definition of adherence, reported adherence rates, study limitations, and implications.
Additional results of relevance, such as predictors of adherence, were abstracted when reported.

\section{Results}

Of the 24 studies included in this review, 16 were prospective observational studies, and 8 were retrospective database or cohort studies. In the following sections, we provide a brief description of the studies included, specific definitions of treatment adherence used, adherence rates by DMT agent and study design, and the relationship between therapy nonadherence and clinical and economic outcomes. Appendix B provides a full description of each study, including the author, year of publication, and study sponsor; treatments and the specific patient population evaluated; mean time since MS diagnosis and mean duration on MS therapy; length of follow-up over which adherence was measured; definition of adherence; and adherence rates reported.

Studies included in this review varied in terms of the patient population, with 11 studies examining patients with RRMS only, $16,23,25-3312$ studies examining patients with any form of MS, $17,18,34-43$ and only 1 study examining the progressive form of the disease exclusively. ${ }^{44}$ Among studies reporting time since MS diagnosis, mean time since diagnosis ranged between 2 and 12 years. All prospective studies included patients who were already on some form of DMT prior to assessing adherence (mean years on therapy ranged from 2 to 6 years across studies). ${ }^{25-39,44}$ Three retrospective studies evaluated adherence specifically among those initiating a DMT,,$^{17,40,42}$ while the remaining 5 either did not specify prior treatment or included patients who had already received treatment with a DMT. ${ }^{16,18,41,43}$

There were 6 different measures used in the literature to measure patient adherence, including 2 variations of the medication possession ratio (MPR; used among 11 studies), the missed dose ratio (MDR; 3 studies), total number of missed doses (2 studies), percentage of days not covered by therapy (2 studies), and no missed doses over a pre-specified time period (7 studies). The MPR was most commonly used to quantify patient adherence and was calculated using either a fixed-interval or variable-interval approach. The fixed-interval approach divided the total number of days supply of a DMT dispensed by a fixed-time interval (e.g., 365 days), while the variable-interval approach divided the total number of days supply by the time (in days) between the first and last dispensing date. The third ratio used was the MDR, which accounted for variability in dosing frequencies across DMTs. The following MDR methodology was used by Siegel et al. (2008): a single missed dose of once-weekly IM IFN $\beta$-la was equated to a weight of 7.5 (i.e., $7.5 \times 4$ doses per month totals 30 days), while a missed dose of once-daily GA was given a weight of 1 (i.e., $1 \times 30$ doses per month totals 30 days). ${ }^{37}$ However, other studies simply reported a total number of missed doses or the percentage with no missed doses over a specific time period, regardless of differing dosing regimens. The most advanced 
Narrative Review of the Literature on Adherence to Disease-Modifying Therapies Among Patients with Multiple Sclerosis

\section{TABLE 2 Rates of Adherence by DMT Agent}

\begin{tabular}{|c|c|c|c|c|c|}
\hline Treatment & Study & Reference & Adherence Rate (\%) & $\mathrm{N}$ & Study Design \\
\hline \multirow[t]{6}{*}{$\overline{I M ~ I F N ~} \beta-1 \mathrm{a}$} & Arroyo $2011^{\mathrm{a}}$ & 25 & 87.5 & 56 & Prospective \\
\hline & Devonshire $2011^{b}$ & 26 & 85.0 & 764 & Prospective \\
\hline & Wicks 2011c & 34 & 84.0 & 87 & Prospective \\
\hline & Treadaway 2009d & 31 & 79.0 & 223 & Prospective \\
\hline & Halpern 2011e & 40 & 62.3 & 2,305 & Retrospective \\
\hline & & & Weighted Meanf $69.4 \%$ & & \\
\hline \multirow[t]{6}{*}{ SC IFN $\beta-1 \mathrm{a}$} & Arroyo $2011^{\mathrm{a}}$ & 25 & 77.6 & 54 & Prospective \\
\hline & Devonshire $2011^{\mathrm{b}}$ & 26 & 73.0 & 511 & Prospective \\
\hline & Wicks 2011c & 34 & 69.0 & 81 & Prospective \\
\hline & Treadaway 2009d & 31 & 68.0 & 149 & Prospective \\
\hline & Halpern $2011^{\mathrm{e}}$ & 40 & 58.5 & 1,211 & Retrospective \\
\hline & & & Weighted Meanf $63.8 \%$ & & \\
\hline \multirow[t]{6}{*}{ SC IFN $\beta-1 b$} & Arroyo $2011^{\mathrm{a}}$ & 25 & 85.2 & 49 & Prospective \\
\hline & Devonshire $2011^{\mathrm{b}}$ & 26 & 70.0 & 571 & Prospective \\
\hline & Wicks 2011c & 34 & 51.0 & 63 & Prospective \\
\hline & Halpern 2011 ${ }^{\mathrm{e}}$ & 40 & 52.2 & 894 & Retrospective \\
\hline & Treadaway 2009d & 31 & 49.0 & 203 & Prospective \\
\hline & & & Weighted Meanf $58.4 \%$ & & \\
\hline \multirow[t]{6}{*}{ SC GA } & Arroyo $2011^{\mathrm{a}}$ & 25 & 80.0 & 52 & Prospective \\
\hline & Devonshire $2011^{\mathrm{b}}$ & 26 & 66.0 & 475 & Prospective \\
\hline & Halpern $2011^{\mathrm{e}}$ & 40 & 55.4 & 2,270 & Retrospective \\
\hline & Treadaway 2009d & 31 & 49.0 & 223 & Prospective \\
\hline & Wicks 2011c & 34 & 49.0 & 101 & Prospective \\
\hline & & & Weighted Mean ${ }^{\mathrm{f}} 56.8 \%$ & & \\
\hline $\begin{array}{l}\text { aAdherence de } \\
{ }^{b} \text { Adherence de } \\
\text { 'Adherence de } \\
\text { dAdherence de } \\
\text { 'Adherence de } \\
\text { fWeighted by } \\
\text { DMT=disease }\end{array}$ & $\begin{array}{l}\text { d injection in past } 4 \mathrm{x} \\
\text { d injection in past } 4 \mathrm{w} \\
\text { at least } 1 \text { dose in past } \\
\text { d injection in past } 4 \mathrm{x} \\
\text { (variable interval); wit } \\
\text { s. }\end{array}$ & $\begin{array}{l}\text { easured at las } \\
\text { C IFN } \beta-1 \text { a u }\end{array}$ & $\begin{array}{l}\text { visit). } \\
\text { reported for } 44 \text { mcg dosing. }\end{array}$ & 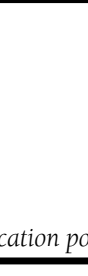 & 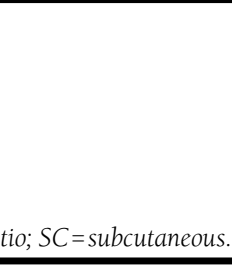 \\
\hline
\end{tabular}

measurement of adherence assessed the percentage of days not covered with a DMT using an electronic Medication Event Monitoring System (MEMS). This system used an electronic monitoring cap to record the date and time of a DMT needle disposal by a patient in order to measure the number of individual days in which a medication was not taken (adjusted for variable dosing frequencies). ${ }^{29}$

When looking across all studies identified in this review, adherence to DMTs ranged between $41 \%$ and $88 \%$, regardless of adherence definition used, type of DMT agent, or study design. Adherence rates were higher for IM IFN $\beta$-la (69.4\%) and SC IFN $\beta-1 \mathrm{a}(63.8 \%)$ than for SC IFN $\beta-1 b(58.4 \%)$ and GA (56.8\%; Table 2 and Figure 2). Of the 6 studies that reported statistical differences in adherence rates by DMT agent, 3 showed that patients treated with IM IFN $\beta$-la had statistically better adherence compared with those treated with SC GA, SC IFN $\beta$-la, or SC IFN $\beta$-1b (in terms of MPR, percentage with at least 1 missed dose in the past month, or mean number of missed doses in the past 28 days). ${ }^{22,34,40}$ An additional study showed IM IFN $\beta-1 a$ to have significantly better adherence than SC IFN $\beta$-la and SC
GA at baseline; however, no significant difference was observed in a survey administered at 2 years of follow-up..$^{25}$ In another study that did not report a specific adherence threshold rate (i.e., did not report a cut-off MPR value to specify adherence), patients treated with IM IFN $\beta$-la had statistically higher MPRs than patients treated with the 3 other DMTs. ${ }^{42}$

When stratifying adherence by study type, adherence was greater among studies with a prospective study design (weighted by study sample size, mean adherence of $72.8 \%$ ) compared with those with a retrospective study design (53.1\%). Of the studies reporting adherence by DMT agent in Table 2, only Halpern et al. (2011) used a retrospective study design. ${ }^{40}$ Among prospective studies only, the weighted mean adherence by DMT agent is IM IFN $\beta-1 \mathrm{a}(83.9 \%)>\mathrm{SC}$ IFN $\beta-1 \mathrm{a}(72.0 \%)>\mathrm{SC}$ IFN $\beta-1 b(64.7 \%)>$ SC GA (60.4\%; Figure 2).

Of particular importance, improved patient adherence to DMTs may lead to better clinical outcomes, including risk of relapse or MS disease progression. In a large retrospective database study using claims data from 2,446 privately insured patients initiating a DMT, patients who were adherent 


\section{FIGURE 2 Mean Adherence by DMT Agent and Study Design (Weighted by Study Sample Sizes)}

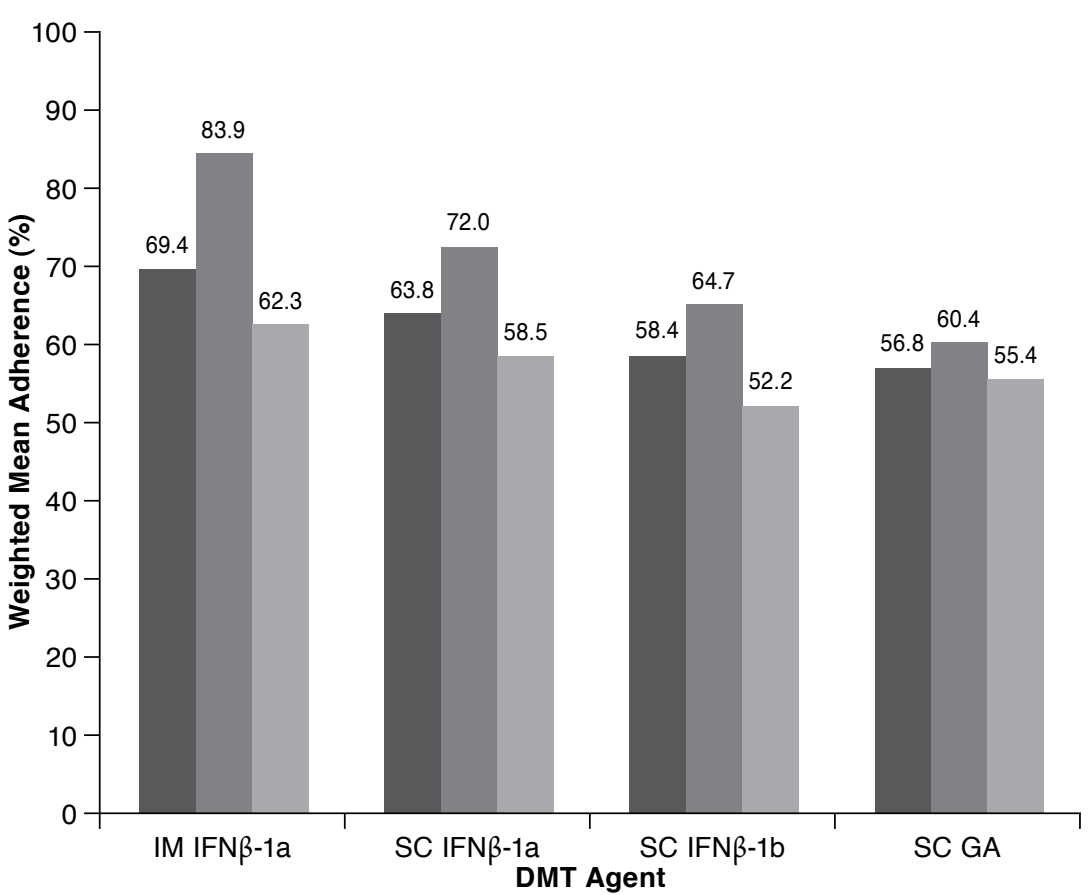

Overall Weighted Mean

Prospective Studies Weighted Mean ${ }^{\mathrm{a}}$

Retrospective Study Mean ${ }^{\mathrm{b}}$

a Prospective studies included the following: Arroyo et al. 2011,25 Devonshire et al. 2011,26 Wicks et al. 2011,34 and Treadaway et al. 2009.31

${ }^{b}$ Retrospective studies included Halpern et al. 2011.40

$D M T=$ disease-modifying therapy; $G A=$ glatiramer acetate; IM = intramuscular; IFN $\beta=$ interferon beta; $S C=$ subcutaneous.

to therapy (defined as an MPR $\geq 80 \%$ ) were significantly less likely to experience a relapse in 1 year of follow-up compared with patients who were nonadherent to therapy (odds ratio $[\mathrm{OR}]=0.71$; 95\% confidence interval [CI] 0.59-0.85), controlling for baseline demographics, health plan type, geographic region, Charlson score (a measure of patient comorbidity burden), specific comorbid conditions, and baseline health care utilization. ${ }^{17}$ In another retrospective database study by Steinberg et al. (2010), it was shown that patients who were adherent to therapy (defined as an MPR $\geq 85 \%$ in the base year of 2005) had a significantly lower risk of relapse in the first year of follow-up (relative risk $[\mathrm{RR}]=0.89 ; 95 \% \mathrm{CI}=0.81$ 0.97; $P<0.05)$; however, this did not hold true in years 2 or 3 of follow-up. ${ }^{16}$ When stratifying based on varying adherence thresholds (MPRs of $<70 \%,<65 \%$, and $<60 \%$ ), lower levels of adherence were significantly associated with a higher risk of relapse any time over the 3 -year study period $(P<0.05){ }^{16}$

In addition to improved clinical outcomes, patients more adherent to a DMT may have lower medical resource utilization and costs. A retrospective study by Tan et al. (2011) found that patients who were adherent to therapy were significantly less likely to experience an MS-related inpatient hospitalization than those who were nonadherent $(\mathrm{OR}=0.63 ; 95 \% \mathrm{CI}=0.47$ -
0.83; $P=0.001)$ and had significantly lower annual MS-related medical costs (excluding pharmacy; adjusted mean $\$ 3,380$ [95\% CI: $\$ 3,046-\$ 3,750]$ vs. $\$ 4,348$ [95\% CI: $\$ 3,828-\$ 4,940$; $P=0.003]) .{ }^{17}$ There was no significant association between adherence and MS-related emergency room (ER) visits. In a separate retrospective study by Steinberg et al. that evaluated all-cause inpatient and ER visits, no significant difference was shown in resource use between adherent and nonadherent patients. ${ }^{16}$

In addition to patient-centered reasons for nonadherence, such as forgetting to inject, self-injection fears and problems, adverse effects, and either real or perceived lack of efficacy, among others, literature also suggests a link between the magnitude of out-of-pocket DMT treatment costs and patient adherence. In a study of 224 patients enrolled in a large multispecialty practice, patients with greater copayments (each $\$ 5$ increase in copayment amount) had significantly lower adherence compared with those with lower copayments $(\mathrm{OR}=0.72$; 95\% CI $=0.57-0.92$, for each $\$ 5$ increase). ${ }^{23}$ However, this association only held for the MPR definition using a fixed denominator (730-day observation period, mean MPR of 68.0\%) versus the variable-interval MPR definition (mean 580-day observation period, mean MPR of $83.8 \%$ ). ${ }^{23}$ Another 
retrospective study of 1,974 commercially insured patients on DMTs found a significant association between coinsurance levels and adherence. ${ }^{41}$ A $10 \%$ increase in cost sharing in the first 6 months following initiation of a DMT was associated with an 8.6\% decline in adherence in the following 12 months (adjusting for demographic variables, Charlson score, and other baseline comorbid diagnoses). ${ }^{41}$

There is some literature pointing to a positive impact of interventional programs on patient adherence to therapy. Stockl et al. (2010) ${ }^{35}$ evaluated the effect of a disease therapy management program on patient adherence to MS therapies compared with those receiving prescriptions through a specialty pharmacy with no disease therapy management program implemented and also with patients receiving prescriptions from a regular retail pharmacy. The disease therapy management program consisted of telephone consultations, a care plan developed by the physician and sent to both the patient and pharmacist, and educational mailings. Results showed that adherence was significantly better in the disease therapy management group (mean [SD] MPR $=0.92$ [0.13]) compared with the retail pharmacy group (mean $[\mathrm{SD}] \mathrm{MPR}=0.86$ [0.18], $P<0.001$ ), but not when compared with the specialty pharmacy-alone group (mean [SD] MPR $=0.90$ [0.16], $P=0.23$ ). ${ }^{35} \mathrm{In}$ a study evaluating the impact of a specialty care management program (consisting of mailed medications and educational materials and nurse assessment phone calls), the mean [SD] MPR of patients participating in the program was significantly higher $(0.86[0.20])$ compared with nonparticipants (0.64 [0.33], $P<0.001$ ). Additionally, participants in the program were significantly less likely to experience an MS-related hospitalization in 1 year of follow-up compared with those not participating in the care management program (adjusted $\mathrm{OR}=0.51,95 \% \mathrm{CI}=0.39-0.67$ ). Total MS-related medical costs (excluding pharmacy) decreased by $\$ 264$ in 1 year of follow-up among program participants while costs increased by $\$ 1,536$ among nonparticipants. ${ }^{18}$

\section{Discussion}

This review of adherence to DMTs found that adherence rates ranged from $41 \%$ to $88 \%$, with lower estimates reported for retrospective (weighted mean adherence 53.1\%) versus prospective study designs (weighted mean adherence $72.8 \%$ ). Among studies reporting adherence by DMT agent, IM IFN $\beta-1$ a was generally associated with the highest rate of adherence (weighted mean adherence 69.4\%). In some studies, patients who were adherent were found to have a lower risk of relapse as well as lower risk of inpatient or ER visits and lower total MS-related costs (excluding pharmacy costs). ${ }^{16,17,32}$

Many other chronic conditions have assessed adherence primarily to oral (not injectable) therapies, making direct comparisons of adherence rates difficult. However, in a recent systematic review of medication adherence among patients with rheumatic conditions, 1 study included in the review assessed adherence to the self-injectable medication etanercept among patients with rheumatoid arthritis (RA). Adherence in this study was assessed through retrospective review of pharmacy records and was defined as an MPR $\geq 80 \% .{ }^{45}$ Adherence over the 1 year following treatment initiation was measured at $68 \%,{ }^{45}$ which is similar to rates (52\%-68\%) reported in 3 database studies of MS therapies that used a similar definition of adherence (MPR $\geq 80 \%$ ). $17,23,40$

This review assessed patient adherence only (evaluating the extent to which patients followed a prescribed dosing schedule over a specified time period) and not persistence (percentage remaining on treatment, i.e., treatment discontinuations). We chose to examine only adherence measures in this review as it provides a fuller evaluation of the patient experience while on treatment. However, future reviews could be focused on the rates of treatment discontinuation among different DMTs. One review by Costello et al. (2008) evaluated this set of literature, citing that approximately $60 \%$ to $76 \%$ of patients remain on IFN $\beta$ or GA for 2 to 5 years. ${ }^{15}$ However, several studies, including an analysis of persistence, have been published since the Costello et al. review, such as the retrospective database analyses by Kleinman et al. (2010), Reynolds et al. (2010), and Wong et al. (2011). Future research is warranted to evaluate persistence to therapy over variable follow-up time periods, specific to each DMT. ${ }^{15,22,42,46}$

There are various pros and cons associated with each of the adherence definitions used in the MS literature. Fixed-interval MPR allows for more consistent comparison of MPRs across studies (providing the same length of time is used for the denominator). However, this approach does not account for any discontinuations in therapy, which may lead to an inaccurate MPR estimate. In comparison, variable-interval MPR does account for patient discontinuations in therapy but may not be as useful for comparison across studies due to highly variable denominators. Studies that did not account for variability in DMT dosing regimens may have over-reported or underreported actual adherence rates dependent upon the specific mix of therapies the patient populations were prescribed. The strictest measure of adherence used in the literature defined patients as adherent only if there were no missed doses within a specified time period. This dichotomous measure does not fully capture the degree of patient adherence, as some patients may have missed only 1 dose while others may have missed several. Not surprisingly, this measure gave the lowest adherence estimates. Finally, one of the retrospective studies identified in this review examined adherence and its association with MS relapse or progression rates over the same follow-up time period. This study design may lead to confounding results, since patients could potentially have exhibited lower adherence due to a relapse, rather than low adherence subsequently causing a relapse. ${ }^{17}$ Future studies should have well-defined baseline periods for assessing adherence and then nonoverlapping follow-up time periods to look for evidence of disease relapse. 
The measures of adherence reported in this review are focused on MPRs and other similar health-economic measures. It should be noted that other definitions of adherence exist that are more patient focused. Adherence in the MS community can alternatively be defined as a patient's continuous, voluntary, and collaborative participation in a mutually accepted behavior, resulting in a specific therapeutic outcome. ${ }^{47}$ This emphasis on patient-provider collaboration is not identified through traditional measurements of adherence (i.e., MPRs), which primarily focuses on a patient's commitment to prescribed dosing intervals.

Generally, prospective studies have relied on patient selfreport for adherence estimates while retrospective studies used prescription claims data. Patient self-report may be inaccurate due to the cognitive decline associated with progressing $\mathrm{MS}^{47}$ and the inability to accurately recall missed doses over the entire observation period (often the prior month). Retrospective claims data are limited in that these analyses assume that all doses filled were properly taken by the patient. In real-world practice, just because a medication was dispensed does not ensure proper administration. Only 1 study in this review utilized an advanced MEMS system that used an electronic monitoring cap to record the date and time of a DMT needle disposal by a patient, thus addressing the issue of actual medication dosing as opposed to simply filling a prescription. ${ }^{29}$ Additionally, there are limitations with the accuracy of coding in retrospective claims data used in retrospective studies. Since DMTs can be covered under both pharmacy and medical benefits, studies based on pharmacy claims alone for evaluation of DMTs prescribed could miss patients whose MS drug coverage was wholly or partially under a medical benefit. For example, 1 study of managed care organizations showed that almost half (49\%) covered self-injectable MS drugs under the pharmacy benefit; 38\% covered them under both the pharmacy and medical benefit; and 13\% covered them under the medical benefit only. ${ }^{48}$

In an analysis of Medicaid claims data versus written medical records, injection frequencies of palivizumab (a humanized monoclonal antibody used to prevent serious respiratory syncytial virus in children) matched for only $46 \%$ of patients. ${ }^{49}$ While this drug is administered in the office setting, unlike the vast majority of MS therapies, it still highlights the lack of accuracy of coding for injectable medications. Finally, 1 retrospective study identified in this review found that DMT adherence ( $\geq 80 \%$ adherent based on using the medication possession ratio) significantly reduced the mean MS relapse rate compared with the rate for patients that were $<80 \%$ adherent over a 12 -month follow-up period $(27.3 \%$ vs. $34.7 \%, P<0.001)$. However, the observation database study was limited by not having data on patient MS type or disability level, although the study groups had similar baseline MS-related symptoms. ${ }^{17}$

This literature review highlights the importance of improved adherence to therapy. Two studies showed a significant asso- ciation between greater treatment adherence and a lower risk of MS relapse, ${ }^{16,17}$ while one showed a significant association between nonadherence and greater MS-related inpatient utilization and total MS-related medical costs. ${ }^{17}$ Another study, which was published after this literature search was conducted, found that adherence to DMTs was associated with a lower rate of severe relapse and lower direct and indirect costs. ${ }^{50}$ These findings are of importance to payers as improved patient adherence may be associated with better patient outcomes and thus lower MS-related medical resource utilization and costs. In order to achieve such savings, there are several opportunities to improve patient adherence. Several studies have pointed to specific patient populations that are at high risk of nonadherence, including patients with high injection anxiety, mental illness, lower perceptions of injection self-efficacy (i.e., the ability to self-inject), or the misconception that the drug is not working for them because they do not see immediate or daily benefits from injections. ${ }^{28-30,33,34,36,39,44}$ The implementation of targeted disease therapy management programs may help to improve adherence among these patients. We identified 2 studies in the recent literature that concluded that use of disease therapy management or interventional programs among broader (nontargeted) cohorts of patients with MS have improved patient adherence to DMTs. ${ }^{17,33}$ If these programs were implemented among the targeted high-risk populations mentioned above, it may be possible to achieve greater adherence, although results would need to be confirmed with a randomized controlled trial.

Two studies have shown a link between higher patient copays or coinsurance and diminished adherence to DMTs, ${ }^{23,41}$ suggesting that reducing patient out-of-pocket (OOP) pharmacy burden may be an opportunity to improve adherence, either through lower copayments or coinsurance levels. However, as these were the only 2 studies identified linking patient financial burden to adherence, further study is needed to confirm these findings. If improvements in adherence were marked enough, there could be opportunities for cost savings in terms of reduced medical resource use. However, there is a need for further study evaluating the direct impact of reduced patient OOP burden on MS relapse rates and associated MS-related medical resource use and costs, as well as costs to payers.

To our knowledge, there is no support in the literature for a direct link between patient adherence to DMTs and healthrelated quality of life (HRQoL). A recent systematic review that evaluated the effect of DMTs on HRQoL in patients with MS concluded that there is evidence from randomized controlled trials (RCTs) and nonrandomized prospective studies that IM and SC IFN $\beta-1$ a or SC IFN $\beta$-lb improves HRQoL in patients with secondary progressive MS. ${ }^{51}$ However, evidence among patients with RRMS is less conclusive as studies used varying instruments that are not directly comparable. ${ }^{51}$ It may be indirectly inferred from available literature that since 
diminished adherence can lead to greater risk of relapse, ${ }^{16,17}$ and progression in disability has been suggested in 1 small prospective study to lower QoL, ${ }^{52}$ adherence may have an impact on a patient's overall HRQoL. Nonetheless, further empirical research is needed to directly quantify the effects of patient adherence to therapy and its effect on QoL.

With the advent of oral therapies, there will likely be concern over the high costs of these novel drugs to patients in addition to payers. If the ease of oral administration significantly improves patient adherence in comparison with standard injectable therapies, there is potential for some cost offsets in the form of lower MS-related medical resource use and costs. In addition, oral therapy has the potential to impact patient QoL by eliminating the need for frequent injections. It will be important to study the effect of oral administration on patient adherence, as well as on the difference in adherence rates between injection and oral administration, in real-world practice.

\section{Conclusions}

Current published literature has shown that lack of medication adherence remains a significant problem among patients with MS. There is a need for further study in this area, such as using reliable and valid adherence measures, conducting studies based on a large nationally representative cohort of patients with MS, understanding the impact of mode of administration or injection frequency on adherence, and evaluating the direct impact of patient OOP burden on DMT adherence and associated MS-related resource use and costs. Large databases contain medical and pharmacy claims data that could be used to examine many of these adherence-related research questions in a retrospective fashion. It is notable, however, that only 6 of the 21 studies identified in this review used retrospective claims data. ${ }^{16-18,40-42}$ Large claims databases also have been used in recent studies to examine MS-related costs. ${ }^{53-55}$ With the rich amount of claims information available to individual health plans, further studies in specific populations to quantify the impact of DMT adherence on clinical and economic outcomes for patients with MS would be of great interest.

Authors

JOSEPH MENZIN, PhD, is President; CHRISTINE NICHOLS, $B A$, is Research and Data Analyst; and MARK FRIEDMAN, MD, is Medical Director, Boston Health Economics, Inc., Waltham, Massachusetts. CHRISTINA CAON, RN, MSN, NP-C, is Assistant Director of Clinical Research and Nurse Practitioner, Wayne State University School of Medicine, Detroit, Michigan; LEIGH ANN WHITE, PhD, is Senior Manager, Health Economics and Outcomes Research, Biogen Idec Inc., Weston, Massachusetts; and MICHAEL W. PILL, PharmD, is President and Chief Medical Officer, Gemini Healthcare, LLC, Westbrook, Connecticut.

\section{DISCLOSURES}

Biogen Idec Inc., the manufacturer of intramuscular interferon beta-la (Avonex), natalizumab (Tysabri), and investigational drugs dimethyl fumarate (BG-12) and PEGylated interferon beta-la, funded the development of this supplement. Editorial assistance was provided by Christopher Barnes and Jacqueline Cannon at Infusion Communications, Inc. Their work was funded by Biogen Idec Inc. Michael Munsell from Boston Health Economics, Inc., contributed to the literature review and manuscript preparation. White is employed by Biogen Idec Inc. Menzin, Friedman, and Nichols received funding from Biogen Idec Inc. Caon has received compensation as a paid consultant to Biogen Idec Inc., Teva Pharmaceuticals, Bayer HealthCare, and Novartis Pharmaceuticals. Caon has also received compensation for lecturing from Teva Pharmaceuticals, Bayer HealthCare, and Novartis Pharmaceuticals. Pill has received compensation for manuscript preparation from Biogen Idec Inc. for previous work. Biogen Idec Inc. reviewed this article and provided feedback to the authors. The authors had full editorial control of the manuscript and provided their final approval of all content.

Menzin, Caon, Nichols, White, Friedman, and Pill contributed to concept and design, data collection, and the writing and revision of the manuscript. Menzin, Caon, White, Friedman, and Pill contributed to data interpretation. The initial manuscript was written primarily by Nichols, and all authors contributed to writing or revision of the manuscript. The authors acknowledge editorial assistance provided by Jacqueline Cannon and Christopher Barnes, from Infusion Communications.

\section{REFERENCES}

1. National Multiple Sclerosis Society. Multiple sclerosis: just the facts. July 2011. Available at: www.nationalmssociety.org/download.aspx?id=22. Accessed October 16, 2012

2. Goodin DS, Frohman EM, Garmany GP Jr., et al. Disease modifying therapies in multiple sclerosis: report of the Therapeutics and Technology Assessment Subcommittee of the American Academy of Neurology and the MS Council for Clinical Practice Guidelines. Neurology. 2002;58(2):169-78.

3. National Multiple Sclerosis Society. What we know about MS: treatments. 2010. Available at: http://www.nationalmssociety.org/about-multiple-sclerosis/what-we-know-about-ms/treatments/index.aspx. Accessed October 16, 2012

4. Betaseron (interferon beta-1b) for SC injection. Bayer HealthCare Pharmaceuticals, Inc. May 2010. Available at: http://berlex.bayerhealthcare $\mathrm{com} / \mathrm{html} /$ products/pi/Betaseron_PI.pdf. Accessed October 16, 2012.

5. AVONEX (interferon beta-la) IM injection. Biogen Idec Inc. Revised October 2012. Available at: http://www.avonex.com/pdfs/guides/Avonex_ Prescribing_Information.pdf. Accessed October 16, 2012.

6. Copaxone (glatiramer acetate injection) solution for subcutaneous injection. TEVA Pharmaceuticals, Inc. February 2009. Available at: http://www. sharedsolutions.com/pdfs/PrescribingInformation.aspx. Accessed October 16,2012

7. Rebif (interferon beta-la) SC injection. EMD Serono, Inc. and Pfizer, Inc. September 2011. Available at: http://www.emdserono.com/cmg.emdserono_ us/en/images/rebif_tcml15_19765.pdf. Accessed October 16, 2012.

8. Tysabri (natalizumab) injection for intravenous use. Biogen Idec Inc. January 2012. Available at: http://www.tysabri.com/en_US/tysb/site/pdfs/ TYSABRI-pi.pdf. Accessed October 16, 2012.

9. Extavia (interferon beta-1b) for subcutaneous injection. Novartis Pharmaceuticals Corporation. March 2012. Available at: http://www.pharma. us.novartis.com/product/pi/pdf/extavia.pdf. Accessed October 16, 2012.

10. Ampyra (dalfampridine) extended release tablets, for oral use. Acorda Therapeutics, Inc. Revised August 2012. Available at: http://ampyra.com/ local/files/PI.pdf. Accessed October 16, 2012.

11. Gilenya (fingolimod) capsules. Novartis Pharmaceuticals Corporation. May 2012. Available at: http://www.pharma.us.novartis.com/product/pi/pdf/ gilenya.pdf. Accessed October 16, 2012. 
12. Novantrone (mitoxantrone) for injection concentrate. EMD Serono. March 2012. Available at: http://www.accessdata.fda.gov/drugsatfda_ docs/label/2012/019297s035lbl.pdf?utm_campaign=Google2\&utm_ source=fdaSearch\&utm_medium=website $\& u$ utm_term=novantrone $\% 20$ (mitoxantrone\&utm_content=8. Accessed October 16, 2012.

13. Brandes DW, Callender T, Lathi E, O'Leary S. A review of diseasemodifying therapies for MS: maximizing adherence and minimizing adverse events. Curr Med Res Opin. 2009;25(1):77-92.

14. Riñon A, Buch M, Holley D, Verdun E. The MS Choices Survey: findings of a study assessing physician and patient perspectives on living with and managing multiple sclerosis. Patient Prefer Adherence. 2011;5:629-43.

15. Costello K, Kennedy P, Scanzillo J. Recognizing nonadherence in patients with multiple sclerosis and maintaining treatment adherence in the long term. Medscape J Med. 2008;10(9):225.

16. Steinberg SC, Faris RJ, Chang CF, Chan A, Tankersley MA. Impact of adherence to interferons in the treatment of multiple sclerosis: a non-experimental, retrospective, cohort study. Clin Drug Investig. 2010;30(2):89-100.

17. Tan H, Cai Q, Agarwal S, Stephenson JJ, Kamat S. Impact of adherence to disease-modifying therapies on clinical and economic outcomes among patients with multiple sclerosis. Adv Ther. 2011;28(1):51-61.

18. Tan H, Yu J, Tabby D, Devries A, Singer J. Clinical and economic impact of a specialty care management program among patients with multiple sclerosis: a cohort study. Mult Scler. 2010;16(8):956-63.

19. Wiendl H, Toyka KV, Rieckmann P, Gold R, Hartung HP, Hohlfeld R. Basic and escalating immunomodulatory treatments in multiple sclerosis: current therapeutic recommendations. J Neurol. 2008;255(10):1449-63. Available at: http://www.springerlink.com/content/e3170410121767x2/fulltext.pdf. Accessed October 16, 2012.

20. Cramer JA, Roy A, Burrell A, et al. Medication compliance and persistence: terminology and definitions. Value Health. 2008;11(1):44-47.

21. Evans C, Tam J, Kingwell E, Oger J, Tremlett H. Long-term persistence with the immunomodulatory drugs for multiple sclerosis: a retrospective database study. Clin Ther. 2012;34(2):341-50.

22. Reynolds MW, Stephen R, Seaman C, Rajagopalan K. Persistence and adherence to disease modifying drugs among patients with multiple sclerosis. Curr Med Res Opin. 2010;26(3):663-74.

23. Lafata JE, Cerghet M, Dobie E, et al. Measuring adherence and persistence to disease-modifying agents among patients with relapsing remitting multiple sclerosis. J Am Pharm Assoc. 2008;48(6):752-57.

24. Higgins JPT, Green S, eds. Cochrane Handbook for Systematic Reviews of Interventions. The Cochrane Collaboration. Version 5.1.0. March 2011. Available at: http://www.cochrane-handbook.org/. Accessed October 16, 2012.

25. Arroyo E, Grau C, Ramo-Tello C, Parra J, Sanchez-Solino O. Adherence to disease-modifying therapies in Spanish patients with relapsing multiple sclerosis: two-year interim results of the global adherence project. Eur Neurol. 2011;65(2):59-67.

26. Devonshire V, Lapierre Y, Macdonell R, et al. The Global Adherence Project (GAP): a multicenter observational study on adherence to diseasemodifying therapies in patients with relapsing-remitting multiple sclerosis. Eur J Neurol. 2011;18(1):69-77.

27. Hancock LM, Bruce JM, Lynch SG. Exacerbation history is associated with medication and appointment adherence in MS.J Behav Med. 2011;34(5):330-35

28. Zwibel H, Pardo G, Smith S, Denney D, Oleen-Burkey M. A multicenter study of the predictors of adherence to self-injected glatiramer acetate for treatment of relapsing-remitting multiple sclerosis. J Neurol. 2011;258(3):402-11.

29. Bruce JM, Hancock LM, Lynch SG. Objective adherence monitoring in multiple sclerosis: initial validation and association with self-report. Mult Scler. 2010;16(1):112-20.
30. Bruce JM, Hancock LM, Arnett P, Lynch S. Treatment adherence in multiple sclerosis: association with emotional status, personality, and cognition. J Behav Med. 2010;33(3):219-27.

31. Treadaway K, Cutter G, Salter A, et al. Factors that influence adherence with disease-modifying therapy in MS. J Neurol. 2009;256(4):568-76.

32. Tremlett H, Van der Mei I, Pittas F, et al. Adherence to the immunomodulatory drugs for multiple sclerosis: contrasting factors affect stopping drug and missing doses. Pharmacoepidemiol Drug Saf. 2008;17(6):565-76.

33. Fraser C, Hadjimichael O, Vollmer T. Predictors of adherence to Copaxone therapy in individuals with relapsing-remitting multiple sclerosis. J Neurosci Nurs. 2001;33(5):231-39.

34. Wicks P, Massagli M, Kulkarni A, Dastani H. Use of an online community to develop patient-reported outcome instruments: the Multiple Sclerosis Treatment Adherence Questionnaire (MS-TAQ). J Med Internet Res. 2011;13(1):e12. Available at: http://www.ncbi.nlm.nih.gov/pmc/articles/ PMC3221333/?tool=pubmed. Accessed October 16, 2012.

35. Stockl KM, Shin JS, Gong S, Harada AS, Solow BK, Lew HC. Improving patient self-management of multiple sclerosis through a disease therapy management program. Am J Manag Care. 2010;16(2):139-44.

36. Turner AP, Williams RM, Sloan AP, Haselkorn JK. Injection anxiety remains a long-term barrier to medication adherence in multiple sclerosis. Rehabil Psychol. 2009;54(1):116-21.

37. Siegel S, Turner A, Haselkorn J. Adherence to disease-modifying therapies in multiple sclerosis: does caregiver social support matter? Rehabil Psychol. 2008;53(1):73-79.

38. Turner AP, Kivlahan DR, Sloan AP, Haselkorn JK. Predicting ongoing adherence to disease modifying therapies in multiple sclerosis: utility of the health beliefs model. Mult Scler. 2007;13(9):1146-52.

39. Fraser C, Morgante L, Hadjimichael O, Vollmer T. A prospective study of adherence to glatiramer acetate in individuals with multiple sclerosis. $J$ Neurosci Nurs. 2004;36(3):120-29.

40. Halpern R, Agarwal S, Dembek C, Borton L, Lopez-Bresnahan M. Comparison of adherence and persistence among multiple sclerosis patients treated with disease-modifying therapies: a retrospective administrative claims analysis. Patient Prefer Adherence. 2011;5:73-84. Available at: http:// www.ncbi.nlm.nih.gov/pmc/articles/PMC3058604/?tool=pubmed. Accessed October 16, 2012

41. Dor A, Lage MJ, Tarrants ML, Castelli-Haley J. Cost sharing, benefit design, and adherence: the case of multiple sclerosis. Adv Health Econ Health Serv Res. 2010;22:175-93.

42. Kleinman NL, Beren IA, Rajagopalan K, Brook RA. Medication adherence with disease modifying treatments for multiple sclerosis among US employees. J Med Econ. 2010;13(4):633-40.

43. Wundes A, Kraft GH, Bowen JD, Gooley TA, Nash RA. Mitoxantrone for worsening multiple sclerosis: tolerability, toxicity, adherence and efficacy in the clinical setting. Clin Neurol Neurosurg. 2010;112(10):876-82.

44. Fraser C, Hadjimichael O, Vollmer T. Predictors of adherence to glatiramer acetate therapy in individuals with self-reported progressive forms of multiple sclerosis. J Neurosci Nurs. 2003;35(3):163-70.

45. Harley CR, Frytak JR, Tandon N. Treatment compliance and dosage administration among rheumatoid arthritis patients receiving infliximab, etanercept, or methotrexate. Am J Manag Care. 2003;9(6 Suppl):S136-S143.

46. Wong J, Gomes T, Mamdani M, Manno M, O'Connor PW. Adherence to multiple sclerosis disease-modifying therapies in Ontario is low. Can J Neurol Sci. 2011;38(3):429-33.

47. Caon C, Saunders C, Smrtka J, Baxter N, Shoemaker J. Injectable disease-modifying therapy for relapsing-remitting multiple sclerosis: a review of adherence data. J Neurosci Nurs. 2010;42(5 Suppl):S5-S9.

48. Edlin M, Sonnenreich P. Trends in managing multiple sclerosis. P T. 2008;33(10):611-14. Available at: http://www.ncbi.nlm.nih.gov/pmc/articles/ PMC2730792/?tool=pubmed. Accessed October 16, 2012. 
49. Jacobson VJ, Feaganes J, Wegner S. Reliability of Medicaid claims versus medical record data: in a cost analysis of palivizumab. Pharmacoeconomics. 2007;25(9):793-800

50. Ivanova JI, Bergman RE, Birnbaum HG, Phillips, AL, Stewart M, Meletiche DM. Impact of medication adherence to disease-modifying drugs on severe relapse and direct and indirect costs among employees with multiple sclerosis in the US. J Med Econ. 2012;15(3):601-09.

51. Miller D, Rudick RA, Hutchinson M. Patient-centered outcomes: translating clinical efficacy into benefits on health-related quality of life. Neurology. 2010;74(Suppl 3):S24-S35.
52. Miller A, Dishon S. Health-related quality of life in multiple sclerosis: the impact of disability, gender and employment status. Qual Life Res. 2006;15(2):259-71.

53. Aforismo J, Pill M, Prescott J. Initiating drug therapy in multiple sclerosis patients: effects on healthcare costs. Am J Pharm Benefits. 2010;2(1):59-65.

54. Brandes DW, Shaya FT, Pill MW. Quantifying the role of natalizumab in health and economic outcomes in multiple sclerosis. Am J Manag Care. 2010;16(6 Suppl):S171-S177.

55. Prescott JD, Factor S, Pill M, Levi GW. Descriptive analysis of the direct medical costs of multiple sclerosis in 2004 using administrative claims in a large nationwide database. J Manag Care Pharm. 2007;13(1):44-52.

\section{APPENDIX A Literature Search Terms}

- ("Multiple Sclerosis" [MeSH] AND "Medication Adherence" [MeSH] $)^{a}$

- ("Multiple Sclerosis" [MeSH]) and (Antirheumatic Agents [MeSH] OR "Medication Adherence" [MeSH])

- ("multiple sclerosis" [MeSH] OR "multiple sclerosis" [All Fields]) AND ("therapy" [Subheading] OR "therapy" [All Fields] OR "treatment" [All Fields] OR "therapeutics" [MeSH] OR "therapeutics" [All Fields]) AND adherence [All Fields]

- ("Multiple Sclerosis" [MeSH] or "Multiple sclerosis" [All Fields]) AND (((((“interferon beta la" [Supplementary Concept]) OR "interferon beta-lb" [Supplementary Concept]) OR "copolymer 1" [Supplementary Concept]) OR "fingolimod" [Supplementary Concept]) OR "Mitoxantrone" [MeSH]) OR "natalizumab" [Supplementary Concept]) AND Adherence [All Fields]

- ("Multiple Sclerosis/drug therapy" [MeSH] OR "Multiple Sclerosis/therapy" [MeSH]) AND (adherence [All Fields] OR persistence [All Fields])

- ("Multiple Sclerosis" [MeSH]) AND "Patient Compliance" [MeSH]

• ("multiple sclerosis" [MeSH] OR "multiple sclerosis" [All Fields]) and ("Medication Possession Ratio" OR "MPR")

All search terms used in MEDLINE (PubMed) searching.

aUsed in PubMed, EMBASE, and Cochrane Register of randomized controlled trials (RCTs).

${ }^{b}$ Used in PubMed and Cochrane Register of RCTs. 


\section{APPENDIX B Description of Studies Included in Literature Review}

\begin{tabular}{|c|c|c|c|c|c|c|c|c|}
\hline \# & $\begin{array}{c}\text { Author } \\
\text { Year Published } \\
\text { (Sponsor) }\end{array}$ & $\begin{array}{c}\text { Treatments } \\
\text { and Sample } \\
\text { Sizes }\end{array}$ & $\begin{array}{l}\text { Population Inclusion/ } \\
\text { Exclusion Criteria }\end{array}$ & $\begin{array}{c}\text { Mean Time Since } \\
\text { MS Diagnosis }\end{array}$ & $\begin{array}{c}\text { Mean } \\
\text { Duration on MS } \\
\text { Therapy }\end{array}$ & $\begin{array}{l}\text { Duration } \\
\text { F/U for } \\
\text { Adherence } \\
\text { Measurement }\end{array}$ & $\begin{array}{l}\text { Definition of } \\
\text { Adherence }\end{array}$ & $\begin{array}{c}\text { Adherence } \\
\text { Rates }\end{array}$ \\
\hline \multicolumn{9}{|c|}{ PROSPECTIVE STUDIES } \\
\hline 1 & $\begin{array}{l}\text { Arroyo } 2011 \\
\left(\text { Biogen Idec) }{ }^{25}\right.\end{array}$ & $\begin{array}{l}\text { SC IFN } \beta-1 \mathrm{a} \\
(22 \mathrm{mcg}, \\
\mathrm{n}=43) \\
\text { SC IFN } \beta-1 \mathrm{a} \\
(44 \mathrm{mcg}, \\
\mathrm{n}=54) \\
\text { SC IFN } \beta-1 b \\
(\mathrm{n}=49) \\
\text { IM IFN } \beta-1 \mathrm{a} \\
(\mathrm{n}=56) \\
\text { SC GA } \\
(\mathrm{n}=52)\end{array}$ & $\begin{array}{l}\text { Spanish patients with } \\
\text { RRMS; > } 18 \text { years old; on } \\
\text { monotherapy with current } \\
\text { DMT for > } 6 \text { months prior to } \\
\text { study enrollment (Spanish } \\
\text { subset of Devonshire } 2011 \\
\text { study population) } \\
\text { Excluded if progressive MS, } \\
\text { patient involved in drug } \\
\text { studies within } 6 \text { months } \\
\text { of enrollment, undergone } \\
\text { treatment with immunosup- } \\
\text { pressive drugs or IVIG in } \\
\text { last } 12 \text { months }\end{array}$ & $\begin{array}{l}6 \text { years } \\
\text { (range } 0-37 \text { ) }\end{array}$ & $\begin{array}{l}28 \text { months } \\
\text { (range 6-124) }\end{array}$ & 2 years & $\begin{array}{l}\text { Not missing a } \\
\text { single DMT } \\
\text { injection in past } \\
4 \text { weeks (by self- } \\
\text { report and by } \\
\text { neurologist report) }\end{array}$ & $\begin{array}{l}\text { At last follow-up } \\
\text { visit: } \\
\text { - } 82.4 \% \text { adherence } \\
\text { rate } \\
\text { - Adherence not } \\
\text { significantly } \\
\text { different across } \\
\text { DMTs }\end{array}$ \\
\hline 2 & $\begin{array}{l}\text { Devonshire } 2011 \\
\text { (Biogen Idec) }^{26}\end{array}$ & $\begin{array}{l}\text { SC IFN } \beta-1 \mathrm{a} \\
(22 \mathrm{mcg}) \\
(\mathrm{n}=245) \\
\text { SC IFN } \beta-1 \mathrm{a} \\
(44 \mathrm{mcg}) \\
(\mathrm{n}=51 \mathrm{l}) \\
\text { SC IFN } \beta-1 \mathrm{~b} \\
(\mathrm{n}=571) \\
\text { IM IFN } \beta-1 \mathrm{a} \\
(\mathrm{n}=764) \\
\text { SC GA } \\
(\mathrm{n}=475)\end{array}$ & $\begin{array}{l}\text { Patients with RRMS; > } 18 \\
\text { years old; on monotherapy } \\
\text { with current DMT for }>6 \\
\text { months prior to study } \\
\text { enrollment } \\
\text { Excluded if progressive MS, } \\
\text { patient involved in drug } \\
\text { studies within } 6 \text { months } \\
\text { of enrollment, undergone } \\
\text { treatment with immunosup- } \\
\text { pressive drugs or IVIG in } \\
\text { last } 12 \text { months } \\
\text { Patients enrolled from } 22 \\
\text { countries }\end{array}$ & $\begin{array}{l}6 \text { years } \\
\text { (range } 0-56)\end{array}$ & $\begin{array}{l}31 \text { months } \\
\text { (range 6-192) }\end{array}$ & 4 weeks & $\begin{array}{l}\text { Not missing } \\
\text { a single DMT } \\
\text { injection in } \\
\text { past } 4 \text { weeks } \\
\text { (patients filled } \\
\text { out retrospective } \\
\text { questionnaire) }\end{array}$ & $\begin{array}{l}\text { Overall: } 75 \% \\
\text { IM IFN } \beta-1 \mathrm{a}: 85 \% \\
\text { SC IFN } \beta-1 \mathrm{a}(22 \\
\text { mcg): } 78 \% \\
\text { SC IFN } \beta-1 \mathrm{a} \text { ( } 44 \\
\text { mcg): } 73 \% \\
\text { SC IFN } \beta-1 b: 70 \% \\
\text { SC GA: } 66 \% \\
\text { Adherence } \\
\text { significantly higher } \\
\text { for IM IFN } \beta-1 \mathrm{a} \\
\text { than all other } \\
\text { DMTs }(P<0.01)\end{array}$ \\
\hline 3 & $\begin{array}{l}\text { Hancock } 2011 \\
\text { (National MS } \\
\text { Society) } 27\end{array}$ & $\begin{array}{l}\text { SC GA }(\mathrm{n}=59) \\
\text { IM IFN } \beta-1 \mathrm{a} \\
(\mathrm{n}=7) \\
\text { SC IFN } \beta-1 \mathrm{~b} \\
(\mathrm{n}=9) \\
\text { *Adherence } \\
\text { not stratified } \\
\text { by treatment } \\
\text { type }\end{array}$ & $\begin{array}{l}\text { Same population as the } \\
\text { Bruce } 2010 \text { (National MS } \\
\text { Society) }{ }^{29} \text { study: } \\
\text { "RRMS patients with no } \\
\text { alcohol/drug abuse, no } \\
\text { other nervous system dis- } \\
\text { order, no relapse and/or } \\
\text { corticosteroid use within } 4 \\
\text { weeks, an absence of severe } \\
\text { physical impairment, and } \\
\text { the use of an injected DMT } \\
\text { for at least } 2 \text { months" }\end{array}$ & $\begin{array}{l}117.38 \text { months } \\
{[S D=90.27]}\end{array}$ & N/A & 8 weeks & $\begin{array}{l}\text { Percentage of } \\
\text { days not covered } \\
\text { by DMT was } \\
\text { monitored using } \\
\text { MEMS (specific } \\
\text { to the prescribed } \\
\text { dosage of DMT, } \\
\text { e.g., missing a } 1 \times \\
\text { weekly dosing } \\
\text { equals } 7 \text { days not } \\
\text { covered) } \\
\text { Additionally, } \\
\text { patient adherence } \\
\text { diaries and self- } \\
\text { report were used }\end{array}$ & $\begin{array}{l}\text { Adherence rates } \\
\text { not reported, only } \\
\text { relational data: } \\
\text { Patients with } \\
\text { higher annualized } \\
\text { relapse rates prior } \\
\text { to start of study } \\
\text { had significantly } \\
\text { lower percentage of } \\
\text { missed doses using } \\
\text { the MEMS, adher- } \\
\text { ence diary, and } \\
\text { self-reported meth- } \\
\text { odology for track- } \\
\text { ing adherence: } \\
\text { - MEMS (r=-0.327, } \\
P<0.01 \text { ) } \\
\text { - Diary ( } r=-0.312 \text {, } \\
P<0.01 \text { ) } \\
\text { - Self-report } \\
(\mathrm{r}=-0.383 \text {, } \\
P<0.01 \text { ) }\end{array}$ \\
\hline
\end{tabular}




\section{APPENDIX B Description of Studies Included in Literature Review (continued)}

\begin{tabular}{|c|c|c|c|c|c|c|c|c|}
\hline \# & $\begin{array}{c}\text { Author } \\
\text { Year Published } \\
\text { (Sponsor) }\end{array}$ & $\begin{array}{c}\text { Treatments } \\
\text { and Sample } \\
\text { Sizes }\end{array}$ & $\begin{array}{l}\text { Population Inclusion/ } \\
\text { Exclusion Criteria }\end{array}$ & $\begin{array}{l}\text { Mean Time Since } \\
\text { MS Diagnosis }\end{array}$ & $\begin{array}{c}\text { Mean } \\
\text { Duration on MS } \\
\text { Therapy }\end{array}$ & $\begin{array}{c}\text { Duration } \\
\text { F/U for } \\
\text { Adherence } \\
\text { Measurement }\end{array}$ & $\begin{array}{l}\text { Definition of } \\
\text { Adherence }\end{array}$ & $\begin{array}{c}\text { Adherence } \\
\text { Rates }\end{array}$ \\
\hline 4 & $\begin{array}{l}\text { Wicks } 2011 \\
\text { (Novartis } \\
\text { Pharmaceuticals } \\
\text { Corp./ } \\
\text { PatientsLikeMe, } \\
\text { Inc.) }{ }^{34}\end{array}$ & $\begin{array}{l}\text { SC GA } \\
(\mathrm{n}=101) \\
\text { IM IFN } \beta-1 \mathrm{a} \\
(\mathrm{n}=87) \\
\text { SC IFN } \beta-1 \mathrm{a} \\
(\mathrm{n}=81) \\
\text { SC IFN } \beta-1 \mathrm{~b} \\
(\mathrm{n}=63)\end{array}$ & $\begin{array}{l}\text { Patients self-reporting a } \\
\text { MS diagnosis recruited } \\
\text { from an online community } \\
\text { (PatientsLikeMe) to par- } \\
\text { ticipate in online survey } \\
\text { (MS-TAQ) } \\
\text { Excluded if did not com- } \\
\text { plete full survey, were tak- } \\
\text { ing mitoxantrone, or pro- } \\
\text { vided inconsistent data } \\
\text { Relapse-remitting form } \\
(n=311 ; 72 \%) \\
\text { Secondary progressive } \\
(n=45 ; 10 \%) \\
\text { Unknown ( } n=17 \text {; } 4 \%) \\
\text { Primary progressive ( } n=17 \text {; } \\
4 \%) \\
\text { Progressive relapsing } \\
(n=16 ; 4 \%)\end{array}$ & 11 years $[S D=9]$ & 22 months & N/A & $\begin{array}{l}\text { MDR = (no. } \\
\text { of doses } \\
\text { missed) } \div \text { (no. of } \\
\text { prescribed doses } \\
\text { in } 28 \text { days) }\end{array}$ & 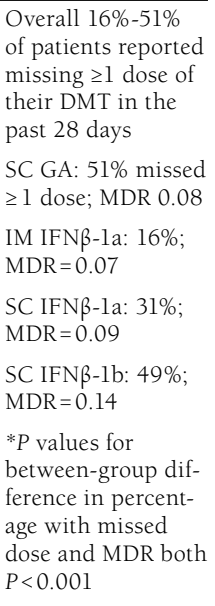 \\
\hline 5 & $\begin{array}{l}\text { Zwibel } 2011 \\
\text { (Teva } \\
\text { Pharmaceuticals) }{ }^{28}\end{array}$ & $\begin{array}{l}\text { SC GA } \\
(\mathrm{N}=234)\end{array}$ & $\begin{array}{l}\text { Patients }>18 \text { years old with } \\
\text { RRMS receiving GA therapy } \\
\text { for the first time. Excluded } \\
\text { if illness other than MS, } \\
\text { hypersensitivity to GA, or } \\
\text { pregnant/breastfeeding } \\
\text { Patients were either: } \\
\text { Treatment-naive (TN): } \\
\text { no prior IMT experience } \\
\text { (n=146) } \\
\text { Treatment-experienced } \\
\text { (TE): had used IFN } \beta \text { ther- } \\
\text { apy previously }(n=88) \text { IM } \\
\text { IFN } \beta \text {-la was most common } \\
\text { prior therapy }\end{array}$ & $\begin{array}{l}\text { Adherent: } 4.2 \\
\text { years [SD }=6.0] \\
\text { Nonadherent: } \\
1.9 \text { years } \\
{[\mathrm{SD}=3.9]}\end{array}$ & N/A & 12 weeks & $\begin{array}{l}\text { Adherence based } \\
\text { on response to the } \\
\text { following: } \\
\text { "Has the patient } \\
\text { used the study } \\
\text { therapy con- } \\
\text { tinuously for the } \\
\text { past month or } 2 \\
\text { months? If the } \\
\text { patient stopped } \\
\text { therapy, is the } \\
\text { patient willing to } \\
\text { restart?" } \\
\text { *If patient stopped } \\
\text { therapy, but was } \\
\text { willing to restart } \\
\text { at office visit, } \\
\text { patient was con- } \\
\text { sidered adherent }\end{array}$ & $\begin{array}{l}\text { TN: } 126 / 146 \\
(86.3 \%) \\
\text { TE: } 76 / 88(86.4 \%)\end{array}$ \\
\hline 6 & $\begin{array}{l}\text { Bruce } 2010 \\
\text { (National MS } \\
\text { Society) }{ }^{29}\end{array}$ & $\begin{array}{l}\text { SC GA }(\mathrm{n}=53) \\
\text { IM IFN } \beta \text {-1a } \\
(\mathrm{n}=5) \\
\text { SC IFN } \beta-1 \mathrm{~b} \\
(\mathrm{n}=9) \\
\text { *Adherence } \\
\text { not stratified } \\
\text { by treatment } \\
\text { type }\end{array}$ & $\begin{array}{l}\text { RRMS patients with no } \\
\text { alcohol/drug abuse, no } \\
\text { other nervous system dis- } \\
\text { order, no relapse and/or } \\
\text { corticosteroid use within } 4 \\
\text { weeks, an absence of severe } \\
\text { physical impairment, and } \\
\text { the use of an injected DMT } \\
\text { for at least } 2 \text { months }\end{array}$ & $\begin{array}{l}10.04 \text { years } \\
{[S D=7.75]}\end{array}$ & $\begin{array}{l}5.91 \text { years } \\
{[\mathrm{SD}=3.69]}\end{array}$ & 8 weeks & $\begin{array}{l}\text { Percentage of DMT } \\
\text { doses missed: } \\
\text { Poor adherence: } \\
20 \% \\
\text { Variable } \\
\text { adherence: } \\
10 \%-19.99 \% \\
\text { Adequate } \\
\text { adherence: } \\
1 \%-9.99 \% \\
\text { Excellent } \\
\text { adherence: } \\
0-0.99 \% \\
\text { Measured using: } \\
\text { MEMS - percent- } \\
\text { age of days not } \\
\text { covered by DMT } \\
\text { Additionally, } \\
\text { patient adherence } \\
\text { diaries and self- } \\
\text { report were used } \\
\text { for percentage of } \\
\text { doses missed }\end{array}$ & $\begin{array}{l}\text { MEMS (\%): } \\
\text { - Poor: } 17.9 \\
\text { - Variable: } 9.0 \\
\text { - Adequate: } 35.8 \\
\text { - Excellent: } 37.3 \\
\text { Adherence diary (\%): } \\
\text { - Poor: } 13.4 \\
\text { - Variable: } 7.5 \\
\text { - Adequate: } 32.9 \\
\text { - Excellent: } 41.8 \\
\text { Prospective self- } \\
\text { report for } 8 \text {-week } \\
\text { study period (\%): } \\
\text { - Poor: } 7.5 \\
\text { - Variable: } 6.0 \\
\text { - Adequate: } 31.3 \\
\text { - Excellent: } 52.2\end{array}$ \\
\hline
\end{tabular}




\section{APPENDIX B Description of Studies Included in Literature Review (continued)}

\begin{tabular}{|c|c|c|c|c|c|c|c|c|}
\hline$\#$ & $\begin{array}{c}\text { Author } \\
\text { Year Published } \\
\text { (Sponsor) }\end{array}$ & $\begin{array}{c}\text { Treatments } \\
\text { and Sample } \\
\text { Sizes }\end{array}$ & $\begin{array}{l}\text { Population Inclusion/ } \\
\text { Exclusion Criteria }\end{array}$ & $\begin{array}{c}\text { Mean Time Since } \\
\text { MS Diagnosis }\end{array}$ & $\begin{array}{c}\text { Mean } \\
\text { Duration on MS } \\
\text { Therapy } \\
\end{array}$ & \begin{tabular}{|c|} 
Duration \\
F/U for \\
Adherence \\
Measurement \\
\end{tabular} & $\begin{array}{l}\text { Definition of } \\
\text { Adherence }\end{array}$ & $\begin{array}{c}\text { Adherence } \\
\text { Rates }\end{array}$ \\
\hline 7 & $\begin{array}{l}\text { Bruce } 2010 \\
\text { (National MS } \\
\text { Society) }{ }^{30}\end{array}$ & $\begin{array}{l}\text { SC GA }(\mathrm{n}=45) \\
\text { IM IFN } \beta-1 \mathrm{a} \\
(\mathrm{n}=3) \\
\text { SC IFN } \beta-1 \mathrm{~b} \\
(\mathrm{n}=7) \\
\text { *Adherence } \\
\text { not stratified } \\
\text { by treatment } \\
\text { type }\end{array}$ & $\begin{array}{l}\text { RRMS patients with no } \\
\text { alcohol/drug abuse, no } \\
\text { other nervous system dis- } \\
\text { order, no relapse and/or } \\
\text { corticosteroid use within } 4 \\
\text { weeks, an absence of severe } \\
\text { physical impairment, and } \\
\text { the use of an injected DMT } \\
\text { for at least } 2 \text { months, no } \\
\text { assistance taking DMT, no } \\
\text { history of learning disabil- } \\
\text { ity, less than } 61 \text { years of age }\end{array}$ & $\begin{array}{l}8.51 \text { years } \\
{[S D=5.99]}\end{array}$ & $\begin{array}{l}5.72 \text { years } \\
{[S D=3.49]}\end{array}$ & 8 weeks & & \\
\hline 8 & $\begin{array}{l}\text { Stockl } 2010 \\
\text { (No outside fund- } \\
\text { ing) }\end{array}$ & $\begin{array}{l}\text { IM IFN } \beta-1 \mathrm{a} \\
(\mathrm{n}=137) \\
\text { SC IFN } \beta-1 \mathrm{~b} \\
(\mathrm{n}=92) \\
\text { SC GA } \\
(\mathrm{n}=149) \\
\text { SC IFN } \beta-1 \mathrm{a} \\
(\mathrm{n}=90) \\
\text { Total } \mathrm{N}=468\end{array}$ & $\begin{array}{l}\text { Claims data population } \\
\text { (disease therapy manage- } \\
\text { ment group): } \\
\text { Completed DMT program } \\
\text { AND had filled prescription } \\
\text { for an injectable MS medi- } \\
\text { cation at the PBM's specialty } \\
\text { pharmacy } \\
\text { Specialty pharmacy group: } \\
\text { Claim for injectable MS } \\
\text { medication in PBM's spe- } \\
\text { cialty pharmacy but did not } \\
\text { complete the therapy man- } \\
\text { agement program } \\
\text { Retail group: Injectable } \\
\text { MS medication claim from } \\
\text { location other than PBM's } \\
\text { specialty pharmacy }\end{array}$ & N/A & N/A & 8 months & $\begin{array}{l}\text { MPR - level for } \\
\text { adherence not } \\
\text { specified; MPRs } \\
\text { compared between } \\
\text { populations } \\
\text { MPR = (no. of days } \\
\text { supply filled in } 8 \\
\text { months F/U) } \div \text { (no. } \\
\text { of days of therapy } \\
\text { between the first } \\
\text { fill and last fill } \\
\text { in F/U plus days' } \\
\text { supply for the } \\
\text { last fill) }\end{array}$ & $\begin{array}{l}\text { MPR: } \\
\text { Therapy manage- } \\
\text { ment group: } 0.92 \\
\text { [SD }=0.13] \\
\text { Specialty phar- } \\
\text { macy group: } 0.90 \\
\text { [SD }=0.16] \\
\text { Retail pharmacy } \\
\text { group: } 0.86 \\
\text { [SD }=0.18] \\
\text { Adherence signifi- } \\
\text { cantly better in the } \\
\text { therapy manage- } \\
\text { ment group com- } \\
\text { pared with retail } \\
\text { pharmacy group } \\
(P<0.001)\end{array}$ \\
\hline 9 & $\begin{array}{l}\text { Treadaway } 2009 \\
\text { (Biogen Idec) }^{31}\end{array}$ & $\begin{array}{l}\text { SC GA } \\
(\mathrm{n}=223) \\
\text { SC IFN } \beta-1 \mathrm{~b} \\
(\mathrm{n}=203) \\
\text { IM IFN } \beta-1 \mathrm{a} \\
(\mathrm{n}=223) \\
\text { SC IFN } 3-1 \mathrm{a} \\
(\mathrm{n}=149)\end{array}$ & $\begin{array}{l}\text { Relapsing form of MS; } 18 \\
\text { years or older; maintained } \\
\text { therapy with } 1 \text { DMT for at } \\
\text { least } 6 \text { months }\end{array}$ & $\begin{array}{l}7.3 \text { years } \\
{[S D=6.28]}\end{array}$ & $\begin{array}{l}\text { All participants } \\
\text { at least } 6 \\
\text { months; } \\
\text { majority }>2 \\
\text { years }\end{array}$ & 2 months & $\begin{array}{l}\text { Missing any } \\
\text { injection in prior } 4 \\
\text { weeks }\end{array}$ & 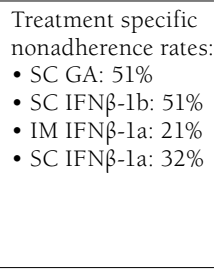 \\
\hline 10 & $\begin{array}{l}\text { Turner } 2009 \\
\text { (Dept. of VA } \\
\text { Rehabilitation } \\
\text { Research) }\end{array}$ & $\begin{array}{l}\text { SC IFN } \beta-1 \mathrm{a} \\
(\mathrm{n}=8) \\
\text { SC IFN } \beta-1 \mathrm{~b} \\
(\mathrm{n}=19) \\
\text { IM IFN } \beta-1 \mathrm{a} \\
(\mathrm{n}=20) \\
\text { SC GA }(\mathrm{n}=42)\end{array}$ & $\begin{array}{l}\text { Patients with diagnosis } \\
\text { of MS and currently self- } \\
\text { administering a DMT, } \\
\text { visiting an outpatient MS } \\
\text { clinic at a VA medical center } \\
\text { ( } \mathrm{N}=89 \text { ). Patients had been } \\
\text { on therapy for a mean of } \\
3.4 \text { years } \\
\text { Excluded if injections } \\
\text { primarily from an injection } \\
\text { clinic nurse or caregiver }\end{array}$ & $11.79[\mathrm{SD}=7.95]$ & $\begin{array}{l}3.43 \text { years } \\
{[\mathrm{SD}=3.29]}\end{array}$ & 6 months & $\begin{array}{l}\text { See definition } \\
\text { below in Turner } \\
2007^{26}(\# 13)\end{array}$ & $\begin{array}{l}\text { Rates primarily } \\
\text { assessed in Bruce } \\
2010^{29} \\
\text { In multivariate } \\
\text { analysis controlling } \\
\text { for demographics, } \\
\text { MS disability, DMT } \\
\text { type, and time on } \\
\text { DMT, higher base- } \\
\text { line injection anxi- } \\
\text { ety significantly } \\
\text { predicted lower } \\
\text { adherence at } 4 \\
\text { months (OR }=0.44 \text {; } \\
95 \% \mathrm{CI}=0.20-0.96) \\
\text { and } 6 \text { months } \\
(\mathrm{OR}=0.53 ; 95 \% \\
\mathrm{CI}=0.28-0.99)\end{array}$ \\
\hline
\end{tabular}




\section{APPENDIX B Description of Studies Included in Literature Review (continued)}

\begin{tabular}{|c|c|c|c|c|c|c|c|c|}
\hline$\#$ & $\begin{array}{l}\text { Author } \\
\text { Year Published } \\
\text { (Sponsor) }\end{array}$ & $\begin{array}{c}\text { Treatments } \\
\text { and Sample } \\
\text { Sizes }\end{array}$ & $\begin{array}{l}\text { Population Inclusion/ } \\
\text { Exclusion Criteria }\end{array}$ & $\begin{array}{l}\text { Mean Time Since } \\
\text { MS Diagnosis }\end{array}$ & $\begin{array}{c}\text { Mean } \\
\text { Duration on MS } \\
\text { Therapy }\end{array}$ & $\begin{array}{l}\text { Duration } \\
\text { F/U for } \\
\text { Adherence } \\
\text { Measurement }\end{array}$ & $\begin{array}{l}\text { Definition of } \\
\text { Adherence }\end{array}$ & $\begin{array}{l}\text { Adherence } \\
\text { Rates }\end{array}$ \\
\hline 11 & $\begin{array}{l}\text { Siegel } 2008 \\
\text { (Dept. of VA } \\
\text { Rehabilitation } \\
\text { Research) }\end{array}$ & $\begin{array}{l}\text { SC IFN } \beta-1 a \\
(n=13) \\
\text { SC IFN } \beta-1 b \\
(n=12) \\
\text { IM IFN } \beta-1 a \\
(n=7) \\
\text { SC GA ( } n=22) \\
\text { *Adherence } \\
\text { not stratified } \\
\text { by treatment } \\
\text { type }\end{array}$ & $\begin{array}{l}\text { Patients visiting a VA medi- } \\
\text { cal center with a diagnosis } \\
\text { of MS, current use of a } \\
\text { DMT, active participation in } \\
\text { medication administration, } \\
\text { and identified a primary } \\
\text { caregiver in their lives }\end{array}$ & $\begin{array}{l}12.96 \text { years } \\
{[S D=7.82]}\end{array}$ & $\begin{array}{l}3.50 \text { years } \\
{[S D=2.94]}\end{array}$ & 6 months & $\begin{array}{l}\geq 80 \% \text { or more of } \\
\text { prescribed doses } \\
\text { (total no. of doses } \\
\text { taken } \div \text { total no. } \\
\text { prescribed) based } \\
\text { on single, self- } \\
\text { report question: } \\
\text { "How many times } \\
\text { have you missed } \\
\text { taking your } \\
\text { DMT in the past } \\
\text { month?" } \\
\text { A weighted metric } \\
\text { was used specific } \\
\text { to each drug's } \\
\text { prescribed dos- } \\
\text { age }- \text { missing a } \\
1 \times \text { weekly dos- } \\
\text { ing equals } 7.5 \\
\text { missed doses (i.e., } \\
7.5 \times 4=30 \text { ) }\end{array}$ & $\begin{array}{l}\text { - Adherent: } 85.1 \% \text {; } \\
\text { CI }=75.6 \%-94.8 \% \\
\text { - Nonadherent: } \\
\text { 15\%; CI =5.2\%- } \\
24.4 \%\end{array}$ \\
\hline 12 & $\begin{array}{l}\text { Tremlett } 2008 \\
\text { (Multiple Sclerosis } \\
\text { International } \\
\text { Federation) }\end{array}$ & $\begin{array}{l}\begin{array}{l}\text { SC IFN } \beta-1 b \\
(\mathrm{n}=67)\end{array} \\
\text { SC high-dose } \\
\text { IFN } \beta \text {-la } \\
(\mathrm{n}=15) \\
\text { SC GA (n=15) } \\
\text { *Adherence } \\
\text { was reported } \\
\text { by drug type; } \\
\text { however, not } \\
\text { highlighted in } \\
\text { results and not } \\
\text { enough power } \\
\text { to reach any } \\
\text { conclusions } \\
\text { on this } \\
\text { comparison }\end{array}$ & $\begin{array}{l}\text { MS confirmed by MRI; able } \\
\text { to walk without assistance } \\
\text { or support; } 2 \text { relapses in } \\
\text { last } 2 \text { years, had RRMS; on } \\
\text { therapy for at least } 1 \text { month, } \\
\text { and taking IMT at first F/U } \\
\text { Population residents of } \\
\text { Australia }\end{array}$ & $\begin{array}{l}10.79 \text { years } \\
{[S D=8.41]}\end{array}$ & $\begin{array}{l}27.8 \text { months } \\
{[S D=19.53]}\end{array}$ & $\begin{array}{l}\text { Mean of } 2.4 \\
\text { years }\end{array}$ & $\begin{array}{l}\text { - "Fully adher- } \\
\text { ent"= missed 0 } \\
\text { doses } \\
\text { - "Missed few } \\
\text { doses" = missed } \\
\text { 1-5 } \\
\text { "Missed multiple } \\
\text { doses" = missed } \\
>5 \\
\text { "History of missed } \\
\text { doses" } \geq 1 \text { missed } \\
\text { dose in month } \\
\text { prior to baseline }\end{array}$ & $\begin{array}{l}26.8 \% \text { fully adher- } \\
\text { ent } \\
50.5 \% \text { missed few } \\
\text { doses } \\
22.7 \% \text { missed } \\
\text { multiple doses } \\
88 \% \text { adhered to } \\
\text { at least } 80 \% \text { of } \\
\text { intended } \\
\text { (prescribed) doses } \\
\text { at each F/U }\end{array}$ \\
\hline 13 & $\begin{array}{l}\text { Turner } 2007 \\
\text { (Dept. of VA } \\
\text { Rehabilitation } \\
\text { Research) }\end{array}$ & $\begin{array}{l}\text { SC IFN } \beta-1 \mathrm{a} \\
(\mathrm{n}=8) \\
\text { SC IFN } \beta-1 \mathrm{~b} \\
(\mathrm{n}=19) \\
\text { IM IFN } \beta-1 \mathrm{a} \\
(\mathrm{n}=20) \\
\text { SC GA }(\mathrm{n}=42)\end{array}$ & $\begin{array}{l}\text { Patients from a VA medical } \\
\text { center with a diagnosis of } \\
\text { MS, current use of } 1 \text { DMT, } \\
\text { and active participation in } \\
\text { medication administration } \\
\text { Excluded if injection } \\
\text { received by nurse or } \\
\text { caregiver }\end{array}$ & $\begin{array}{l}11.79 \text { years } \\
{[S D=7.95]}\end{array}$ & $\begin{array}{l}3.43 \text { years } \\
{[S D=3.29]}\end{array}$ & 6 months & $\begin{array}{l}\text { MPR }=\text { (no. of doses } \\
\text { taken) } \div \text { (no. of } \\
\text { doses prescribed } \\
\text { in } 1 \text { month) } \\
\text { Adherent: } \\
\text { MPR } \geq 80 \%\end{array}$ & $\begin{array}{l}\text { Adherence rates } \\
\text { by F/U: } \\
\text { - } 2 \text { months: } 88.1 \% \\
(\mathrm{n}=59) \\
\text { - } 4 \text { months: } 86.3 \% \\
(\mathrm{n}=69) \\
\text { - } 6 \text { months: } 87.1 \% \\
(\mathrm{n}=74)\end{array}$ \\
\hline 14 & $\begin{array}{l}\text { Fraser } 2004 \\
\text { (Teva } \\
\text { Neuroscience) } \\
\text { (39 }\end{array}$ & $\begin{array}{l}\text { SC GA } \\
(\mathrm{N}=104)\end{array}$ & $\begin{array}{l}\text { Patients diagnosed with MS } \\
\text { (either RRMS or progressive } \\
\text { MS) initiating GA therapy, } \\
\geq 18 \text { years old }\end{array}$ & $\begin{array}{l}\text { Adherent: } 3.9 \\
{[S D=5.2]} \\
\text { Nonadherent: } \\
6.3[S D=6.5]\end{array}$ & $\begin{array}{l}\text { Initiating } \\
\text { therapy }(+21 \\
\text { days })\end{array}$ & 6 months & $\begin{array}{l}\text { Continuous ther- } \\
\text { apy with SC GA } \\
\text { from therapy } \\
\text { initiation to } \\
6 \text {-month F/U }\end{array}$ & $\begin{array}{l}79 \%(n=82) \text { adher- } \\
\text { ent } \\
21 \%(n=22) \text { nonad- } \\
\text { herent }\end{array}$ \\
\hline 15 & $\begin{array}{l}\text { Fraser } 2003 \\
\text { (Teva } \\
\text { Neuroscience) }\end{array}$ & $\begin{array}{l}\text { SC GA } \\
(\mathrm{N}=199)\end{array}$ & $\begin{array}{l}\text { Patients identified from the } \\
\text { CMSC/NARCOMS Patient } \\
\text { Registry database and the } \\
\text { Shared Solutions MS patient } \\
\text { support database with self- } \\
\text { reported progressive forms } \\
\text { of MS and had taken or } \\
\text { discontinued therapy with } \\
\text { SC GA } \\
\text { Excluded if RRMS (sample } \\
\text { analyzed in Fraser } 2001^{33} \\
\text { publication) or taking } \\
\text { multiple DMTs }\end{array}$ & $\begin{array}{l}\text { Adherent: } 11 \\
\text { years } \\
\text { Nonadherent: } 10 \\
\text { years }\end{array}$ & $\begin{array}{l}\text { Adherent: } 22 \\
\text { months } \\
\text { Nonadherent: } 8 \\
\text { months }\end{array}$ & 1 year & $\begin{array}{l}\text { Adherence defined } \\
\text { as continuous } \\
\text { therapy with SC } \\
\text { GA for at least } \\
\text { l year }\end{array}$ & $\begin{array}{l}54 \%(\mathrm{n}=107) \\
\text { adherent } \\
46 \%(\mathrm{n}=92) \text { nonad- } \\
\text { herent }\end{array}$ \\
\hline
\end{tabular}




\section{APPENDIX B Description of Studies Included in Literature Review (continued)}

\begin{tabular}{|c|c|c|c|c|c|c|c|c|}
\hline$\#$ & $\begin{array}{l}\text { Author } \\
\text { Year Published } \\
\text { (Sponsor) }\end{array}$ & $\begin{array}{c}\text { Treatments } \\
\text { and Sample } \\
\text { Sizes }\end{array}$ & $\begin{array}{l}\text { Population Inclusion/ } \\
\text { Exclusion Criteria }\end{array}$ & $\begin{array}{l}\text { Mean Time Since } \\
\text { MS Diagnosis }\end{array}$ & $\begin{array}{c}\text { Mean } \\
\text { Duration on MS } \\
\text { Therapy }\end{array}$ & $\begin{array}{l}\text { Duration } \\
\text { F/U for } \\
\text { Adherence } \\
\text { Measurement }\end{array}$ & $\begin{array}{l}\text { Definition of } \\
\text { Adherence }\end{array}$ & $\begin{array}{c}\text { Adherence } \\
\text { Rates }\end{array}$ \\
\hline 16 & $\begin{array}{l}\text { Fraser } 2001 \\
\text { (Teva } \\
\text { Neuroscience) } 33\end{array}$ & $\begin{array}{l}\text { SC GA } \\
(\mathrm{N}=341)\end{array}$ & $\begin{array}{l}\text { Patients identified from the } \\
\text { CMSC/NARCOMS Patient } \\
\text { Registry database and the } \\
\text { Shared Solutions MS patient } \\
\text { support database who had } \\
\text { RRMS and had taken or } \\
\text { discontinued therapy with } \\
\text { SC GA } \\
\text { Excluded if had progressive } \\
\text { types of MS or taking } \\
\text { multiple DMTs }\end{array}$ & $\begin{array}{l}\text { Adherent: } 7.36 \\
\text { years [SD }=6.35] \\
\text { Nonadherent: } \\
7.59 \text { years } \\
{[S D=7.39]}\end{array}$ & $\begin{array}{l}\text { Adherent: } \\
21.99 \text { months } \\
\text { [SD = 10.46] } \\
\text { Nonadherent: } \\
5.52 \text { months } \\
{[S D=5.28]}\end{array}$ & 1 year & $\begin{array}{l}\text { Adherence defined } \\
\text { as continuous } \\
\text { therapy with SC } \\
\text { GA for at least } \\
1 \text { year }\end{array}$ & $\begin{array}{l}66 \%(n=225) \\
\text { adherent } \\
34 \%(n=116) \\
\text { nonadherent }\end{array}$ \\
\hline \multicolumn{9}{|c|}{ RETROSPECTIVE STUDIES } \\
\hline 17 & $\begin{array}{l}\text { Halpern } 2011 \\
\text { (Biogen Idec) }^{40}\end{array}$ & $\begin{array}{l}\text { IM IFN } \beta-1 \mathrm{a} \\
(\mathrm{n}=2,305) \\
\text { SC IFN } \beta-1 \mathrm{a} \\
(\mathrm{n}=1,211) \\
\text { SC IFN } \beta-1 b \\
(n=894) \\
\text { SC GA } \\
(n=2,270)\end{array}$ & $\begin{array}{l}\text { Patients with } \geq 1 \text { claim with } \\
\text { diagnosis of MS and } \geq 1 \\
\text { claim for a DMT; commer- } \\
\text { cially insured population } \\
\text { Excluded if taking Extavia } \\
\text { or had index claim with } \\
\text { HCPCS code J1825 and } \\
\text { no subsequent claims that } \\
\text { identified IM/SC INF } \beta \text {-la }\end{array}$ & N/A & $\begin{array}{l}\text { N/A; patients } \\
\text { initiating } \\
\text { treatment }\end{array}$ & N/A & $\begin{array}{l}\text { MPR = (total } \\
\text { days supply dis- } \\
\text { pensed) } \div \text { (total no. } \\
\text { of days from index } \\
\text { Rx to switch or } \\
\text { end of F/U) } \\
\text { Adherent: } \\
\text { MPR } \geq 80 \%\end{array}$ & $\begin{array}{l}\text { IM IFN } \beta-1 \mathrm{a}: 62 \% \\
\text { SC IFN } \beta-1 \mathrm{a}: 59 \% \\
\text { (OR vs. IM } \\
\text { IFN } \beta-1 \mathrm{a}=0.829 \\
\mathrm{CI}=0.719-0.957) \\
\text { SC IFN } \beta-1 \mathrm{~b}: 52 \% \\
(\mathrm{OR}=0.656 ; \\
\mathrm{CI}=0.561-0.768) \\
\text { SC GA: } 55 \% \\
(\mathrm{OR}=0.749 \\
\mathrm{CI}=0.665-0.844) \\
\text { Overall compari- } \\
\text { son, } P<0.001\end{array}$ \\
\hline 18 & $\begin{array}{l}\text { Tan } 2011 \\
(\text { Biogen Idec) })^{17}\end{array}$ & $\begin{array}{l}\text { IM IFN } \beta-1 \mathrm{a} \\
(\mathrm{n}=734) \\
\text { SC IFN } \beta-1 \mathrm{a} \\
(\mathrm{n}=543) \\
\text { SC IFN } \beta-1 \mathrm{~b} \\
(\mathrm{n}=303) \\
\text { SC GA } \\
(\mathrm{n}=866) \\
\text { *Adherence } \\
\text { not stratified } \\
\text { by treatment } \\
\text { type }\end{array}$ & $\begin{array}{l}\text { Patients with } \geq 1 \text { claim with } \\
\text { diagnosis of MS and } \geq 1 \\
\text { claim for a DMT; treatment } \\
\text { naive for } 6 \text {-month baseline; } \\
\text { commercially insured popu- } \\
\text { lation using HealthCore } \\
\text { Integrated Research } \\
\text { Database } \\
\text { Patients aged }>65 \text { years } \\
\text { excluded }\end{array}$ & N/A & $\begin{array}{l}\text { N/A; patients } \\
\text { initiating } \\
\text { treatment }\end{array}$ & 12 months & $\begin{array}{l}\text { MPR = (total } \\
\text { days supply dis- } \\
\text { pensed } \div \text { (total no. } \\
\text { of days in F/U) } \\
\text { Adherent: } \\
\text { MPR } \geq 80 \%\end{array}$ & $\begin{array}{l}\text { Overall, } 59.6 \% \\
\text { were adherent in } \\
\text { l-year F/U }\end{array}$ \\
\hline 19 & $\begin{array}{l}\text { Dor } 2010 \\
\text { (Not reported) }^{41}\end{array}$ & $\begin{array}{l}\text { IM IFN } \beta \text {-la } \\
\text { SC IFN } \beta \text {-la } \\
\text { SC IFN } \beta \text {-lb } \\
\text { GA } \\
\text { (Overall } \\
\mathrm{N}=1,974) \\
\text { *Adherence } \\
\text { not stratified } \\
\text { by treatment } \\
\text { type }\end{array}$ & $\begin{array}{l}\text { Patients with } \geq 1 \text { diagnosis } \\
\text { of MS and } \geq 1 \text { prescription } \\
\text { claim or procedure code } \\
\text { for a DMT; commercially } \\
\text { insured population using } \\
\text { MedStat Marketscan } \\
\text { Database } \\
\text { Excluded if had negative } \\
\text { total copayments, both } \\
\text { copayments and coinsur- } \\
\text { ance in post-period, or total } \\
\text { nonpositive number of days } \\
\text { supplied }\end{array}$ & N/A & Not reported & 1.5 years & $\begin{array}{l}\text { MPR=(total no. } \\
\text { of days supply } \\
\text { prescribed }) \div 365\end{array}$ & $\begin{array}{l}\text { Copayment cohort: } \\
\text { Mean } \\
\text { MPR }=0.72 \pm 0.26 \\
\text { Coinsurance } \\
\text { cohort: } \\
\text { Mean } \\
\text { MPR }=0.66 \pm 0.30 \\
\text { Overall: } \\
\text { Mean } \\
\text { MPR }=0.69 \pm 0.28\end{array}$ \\
\hline 20 & $\begin{array}{l}\text { Kleinman } 2010 \\
\text { (Biogen Idec) }^{42}\end{array}$ & $\begin{array}{l}\text { IM IFN } \beta-1 \mathrm{a} \\
(\mathrm{n}=179) \\
\text { SC IFN } \beta-1 \mathrm{a} \\
(\mathrm{n}=20) \\
\text { SC IFN } \beta-1 \mathrm{~b} \\
(\mathrm{n}=63) \\
\text { SC GA }(\mathrm{n}=96)\end{array}$ & $\begin{array}{l}\text { Patients with diagnosis of } \\
\text { MS and a claim for a DMT, } \\
\text { or }>2 \text { claims for a DMT; } \\
\text { commercially insured } \\
\text { population using Human } \\
\text { Capital Management } \\
\text { Services Research Reference } \\
\text { Database. Excluded patients } \\
\text { with > } 1 \text { DMT agent in } \\
\text { l-year F/U (i.e., patients } \\
\text { who switched) }\end{array}$ & N/A & $\begin{array}{l}\text { N/A; patients } \\
\text { initiating } \\
\text { treatment }\end{array}$ & 12 months & $\begin{array}{l}\text { MPR = (total } \\
\text { days supply } \\
\text { dispensed } \div 365\end{array}$ & $\begin{array}{l}\text { IM IFN } \beta-1 \mathrm{a}: \\
0.782 \pm 0.021 \\
\text { SC IFN } \beta-1 \mathrm{a}: \\
0.761 \pm 0.049 \\
\text { SC IFN } \beta-1 b: \\
0.705 \pm 0.036 \\
\text { SC GA: } \\
0.698 \pm 0.028\end{array}$ \\
\hline
\end{tabular}




\section{APPENDIX B Description of Studies Included in Literature Review (continued)}

\begin{tabular}{|c|c|c|c|c|c|c|c|c|}
\hline \# & $\begin{array}{c}\text { Author } \\
\text { Year Published } \\
\text { (Sponsor) }\end{array}$ & $\begin{array}{c}\text { Treatments } \\
\text { and Sample } \\
\text { Sizes }\end{array}$ & $\begin{array}{l}\text { Population Inclusion/ } \\
\text { Exclusion Criteria }\end{array}$ & $\begin{array}{l}\text { Mean Time Since } \\
\text { MS Diagnosis }\end{array}$ & $\begin{array}{c}\text { Mean } \\
\text { Duration on MS } \\
\text { Therapy }\end{array}$ & $\begin{array}{l}\text { Duration } \\
\text { F/U for } \\
\text { Adherence } \\
\text { Measurement }\end{array}$ & $\begin{array}{l}\text { Definition of } \\
\text { Adherence }\end{array}$ & $\begin{array}{l}\text { Adherence } \\
\text { Rates }\end{array}$ \\
\hline 21 & $\begin{array}{l}\text { Steinberg } 2010 \\
\text { (Merck-Serono) }^{16}\end{array}$ & $\begin{array}{l}\text { IFN } \beta \text {-lb or } \\
\text { IFN } \beta \text {-la } \\
\text { (Overall } \\
N=1,606) \\
\text { *Adherence } \\
\text { not stratified } \\
\text { by treatment } \\
\text { type }\end{array}$ & $\begin{array}{l}\text { RRMS patients with } \geq 2 \\
\text { claims for an INF } \beta \text { treat- } \\
\text { ment in } 2005 \text { (with no } \\
\text { requirements for a claim in } \\
\text { F/U); commercially insured } \\
\text { population } \\
\text { Patients excluded if taking } \\
\text { Extavia as the study period } \\
\text { preceded U.S. approval } \\
\text { (August 2009) }\end{array}$ & N/A & Not reported & N/A & $\begin{array}{l}\text { MPR = (total days } \\
\text { supply dispensed } \\
360 \text { days following } \\
\text { index Rx } \div 360 \\
\text { days } \\
\text { Adherent: } \\
\text { MPR } \geq 85 \%\end{array}$ & $\begin{array}{l}\text { Proportion defined } \\
\text { as adherent } \\
\text { (defined as MPR } \\
\geq 85 \% \text { ) ranged from } \\
27 \%-41 \% \text { in each } \\
\text { individual year; } 4 \% \\
\text { over entire 3-year } \\
\text { period } \\
\text { Average MPR } \\
\text { ranged from } 72 \% \text { - } \\
76 \% \text { in each year } \\
\end{array}$ \\
\hline 22 & $\begin{array}{l}\text { Tan } 2010 \\
\text { (WellPoint Inc.) }^{18}\end{array}$ & $\begin{array}{l}\text { IM IFN } \beta \text {-la } \\
(\mathrm{n}=1,489) \\
\text { SC IFN } \beta \text {-la } \\
(\mathrm{n}=663) \\
\text { SC IFN } \beta \text {-1b } \\
(\mathrm{n}=539) \\
\text { SC GA } \\
(\mathrm{n}=1,254) \\
\text { *Adherence } \\
\text { not stratified } \\
\text { by treatment } \\
\text { type }\end{array}$ & $\begin{array}{l}\text { Patients with } \geq 2 \text { claims } \\
\text { with diagnosis of MS and } \\
\geq 1 \text { claim for a DMT; com- } \\
\text { mercially insured popula- } \\
\text { tion using HealthCore } \\
\text { Integrated Research } \\
\text { Database }\end{array}$ & N/A & $\begin{array}{l}\text { Program } \\
\text { participant: } \\
16.8 \text { months } \\
\text { [SD }=10.1] \\
\text { Nonparticipant: } \\
14.6 \text { months } \\
{[S D=9.8]}\end{array}$ & 12 months & $\begin{array}{l}\text { MPR }=\text { (total } \\
\text { days supply dis- } \\
\text { pensed } \div \text { (total no. } \\
\text { of days in } \mathrm{F} / \mathrm{U})\end{array}$ & $\begin{array}{l}\text { Participants in } \\
\text { specialty program: } \\
\text { MPR }=0.86 \pm 0.20 \\
\text { Not participating in } \\
\text { specialty program: } \\
\text { MPR }=0.64 \pm 0.33 \\
\text { Difference } P<0.001\end{array}$ \\
\hline 23 & $\begin{array}{l}\text { Wundes } 2010 \\
\text { (NIAID, United } \\
\text { Spinal Association, } \\
\text { National MS } \\
\text { Society, NIDRR) } 43\end{array}$ & $\begin{array}{l}\text { Mitoxantrone- } \\
\text { intended treat- } \\
\text { ment regimen: } \\
\mathrm{IV} 12 \mathrm{mg} / \\
\mathrm{m}^{2} \text { every } 3 \\
\text { months for a } \\
\text { total lifetime } \\
\text { infusion of } \\
140 \mathrm{mg} / \mathrm{m}^{2} \\
(\mathrm{~N}=96)\end{array}$ & $\begin{array}{l}\text { Patients with worsening MS } \\
\text { treated at the University } \\
\text { of Washington, with }>1 \\
\text { mitoxantrone infusion; } 81 \\
\text { initiated treatment due to } \\
\text { disease progression, intoler- } \\
\text { ance of first-line treatment } \\
(\mathrm{n}=16) \text {, or nonadherence to } \\
\text { first-line treatment }(\mathrm{n}=9)\end{array}$ & $\begin{array}{l}\text { 9.7 years (range } \\
0.3-37.4 \text { ) } \\
\text { * Disease dura- } \\
\text { tion at DMT } \\
\text { initiation }\end{array}$ & Not reported & $\begin{array}{l}\text { Group A: } 28 \\
\text { months } \\
\text { Group B: } 37 \\
\text { months } \\
\text { Group C: } 53 \\
\text { months } \\
\text { *Groups } \\
\text { based } \\
\text { on total } \\
\text { infusions } \\
\text { received }\end{array}$ & $\begin{array}{l}\text { Dose reductions } \\
\text { or deviations from } \\
\text { prescribed dosing } \\
\text { interval }\end{array}$ & $\begin{array}{l}11 \% \text { of all infusions } \\
\text { were administered } \\
\text { at doses }<12 \mathrm{mg} / \\
\mathrm{m}^{2} \\
32.1 \% \text { of infusions } \\
\text { were given accord- } \\
\text { ing to the intended } \\
\text { dosing schedule } \\
\text { of once every } 3 \\
\text { months }\end{array}$ \\
\hline 24 & $\begin{array}{l}\text { Lafata } 2008 \\
\text { (Teva } \\
\text { Neuroscience) } 23\end{array}$ & $\begin{array}{l}\text { IM IFN } \beta \text {-la } \\
\text { SC IFN } \beta \text {-la } \\
\text { SC IFN } \beta \text {-lb } \\
\text { SC GA } \\
\text { (Overall } \\
\mathrm{N}=224) \\
\text { *Adherence } \\
\text { not stratified } \\
\text { by treatment } \\
\text { type }\end{array}$ & $\begin{array}{l}\text { Patients with } \geq 1 \text { IP or } \geq 2 \\
\text { OP claims with diagnosis of } \\
\text { MS, with diagnosis of MS } \\
\text { (including type) verified } \\
\text { by chart review; cohort of } \\
\text { patients receiving care from } \\
\text { large multispecialty practice } \\
\text { in Michigan }\end{array}$ & N/A & N/A & 2 years & $\begin{array}{l}\text { Definition } 1 \text { : } \\
\text { MPR = (total } \\
\text { days supply dis- } \\
\text { pensed) } \div \text { (total no. } \\
\text { of days between } \\
\text { first and last dis- } \\
\text { pensing date) } \\
\text { Definition } 2 \text { : } \\
\text { MPR = (total } \\
\text { days supply dis- } \\
\text { pensed) } \div \text { (total } \\
\text { no. of days in } \\
\text { observation period } \\
{[730 \text { days]) }} \\
\text { Adherent: } \\
\text { MPR } \geq 80 \%\end{array}$ & $\begin{array}{l}\text { Definition 1: } 83.8 \% \\
\text { Definition 2: } 68.0 \%\end{array}$ \\
\hline
\end{tabular}

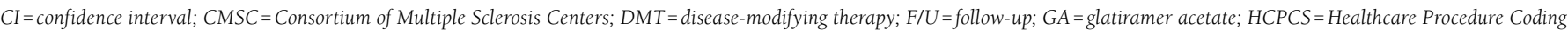

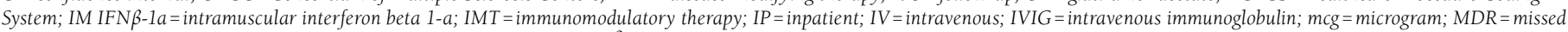
dose ratio; MEMS = Medication Event Monitoring System; $m g=$ milligram; $m^{2}=$ meters squared; MPR=medication possession ratio; MS-TAQ= Multiple Sclerosis Treatment Adherence

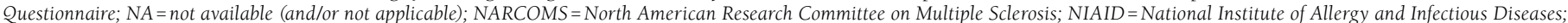
NIDRR = National Institute on Disability and Rehabilitation Research; $O P=$ outpatient: $O R=$ odds ratio; $P B M=$ pharmacy benefit manager; $R R M S=$ relapsing-remitting multiple sclerosis; $r=$ correlation coefficient; $R x=$ prescription; SC IFN $\beta-1 a=$ subcutaneous interferon beta $1-a$; SC IFN $\beta-1 b=$ subcutaneous interferon beta 1 - $b$; SC GA=subcutaneous glatiramer acetate; $S D=$ standard deviation; $T E=$ treatment experienced; $T N=$ treatment naïve; VA=Veterans Affairs. 


\title{
Perspectives for Managed Care Organizations on the Burden of Multiple Sclerosis and the Cost-Benefits of Disease-Modifying Therapies
}

\author{
Gary M. Owens, MD; Eleanor L. Olvey, PharmD, PhD; \\ Grant H. Skrepnek, PhD; and Michael W. Pill, PharmD
}

\begin{abstract}
Disease-modifying therapies (DMTs) are a core component of multiple sclerosis (MS) management. Given current constraints on health care expenditures, the relative cost-effectiveness of these therapies needs to be considered when making treatment decisions. The objective of this article is to review the burden of illness of MS, discuss the cost-effectiveness data for DMTs, and summarize the implications for payers.

For the burden of illness in MS, a retrospective analysis of managed care administrative data from the IMS LifeLink Health Plan Claims Database was performed. Data from claims submitted for patients with confirmed MS (ICD-9-CM code 340) over a period of 1 year (2009) were analyzed. A literature review was conducted to put these data into perspective.

The retrospective analysis determined that the mean annual cost of treating MS in the United States in 2009 was $\$ 23,434$, which varied according to the presence of comorbidities/complications. Overall, DMTs accounted for $69 \%$ of the total costs of managing the disease. According to the literature review, the typical first-line DMTs (interferon beta [IFN $\beta$ ] formulations and glatiramer acetate [GA]) are generally associated with incremental cost-utility or cost-effectiveness ratios in excess of $\$ 100,000$ per quality of life year gained. Natalizumab may have cost benefits over other agents in patients with more aggressive disease. According to the available data, studies indicate that DMT cost-effectiveness (specifically cost per quality-adjusted life years) appears to improve with treatment initiation during the early stages of the disease.

In relapsing-remitting MS, there is currently little evidence to differentiate between the DMTs that are typically used first-line (IFNs and GA) based on cost-effectiveness or cost-utility studies. Presently, optimal therapy decisions for DMT-naïve patients are likely to be made individually based on patient and provider preference, adherence, and medication risk-benefit profiles. For patients with more advanced disease, natalizumab appears to have greater efficacy and to be more cost-effective than other agents.
\end{abstract}

J Manag Care Pharm. 2013;19(1-a):S41-S53

Copyright $\odot 2013$, Academy of Managed Care Pharmacy. All rights reserved.

\section{Summary Points Presented in this Article}

- Multiple sclerosis (MS) is a progressive inflammatory and degenerative autoimmune disease of the central nervous system. Most individuals are diagnosed with MS between 20-40 years of age, and there is currently no cure for MS.

- Both pharmacologic and nonpharmacologic interventions are used to manage MS. Disease-modifying therapies (DMTs) are a core component of the pharmacological management of this disease.

- Continuous therapy for MS results in substantial health care expenditures.

- This report presents a retrospective analysis of the cost burden of illness with MS, reports the results of an assessment of the costeffectiveness of injectable DMTs for MS, reviews the impact of MS on patient work productivity, and summarizes the implications for the managed care audience.

\section{Summary Points Presented in this Article (continued)}

- According to the retrospective analysis, DMTs account for $69 \%$ of the total cost to treat MS in the United States and are associated with high incremental cost-effectiveness ratios ranging from $\$ 20,000$ to more than $\$ 1$ million per quality of life year gained. In line with efficacy findings, cost-effectiveness is improved by initiating treatment in early disease stages.

- In relapsing-remitting MS, there is currently little evidence to differentiate between the DMTs that are typically used first-line (interferon betas and glatiramer acetate) based on cost-effectiveness or cost-utility studies.

- Optimal therapy decisions for DMT-naïve patients are likely to be made individually based on disease presentation, patient and provider preference, adherence, and medication risk-benefit profiles.

$\mathrm{M}$ ultiple sclerosis (MS) is a progressive inflammatory and degenerative disease of the central nervous system (CNS) that is thought to be autoimmune in nature. Most individuals diagnosed with MS experience their first clinical symptoms between 20-40 years of age. Initial signs of illness may include weakness, sensory symptoms, ataxia, visual symptoms, diplopia, and vertigo. ${ }^{2}$ These symptoms intensify and abate with relapses or exacerbations separated by periods of stability. Over time, these symptoms accumulate and persist, and other negative effects arise such as bowel and bladder dysfunction, fatigue, muscle spasms, speech disorders, memory loss, and other neuropsychiatric signs. ${ }^{2}$ Ultimately, these effects become increasingly permanent, resulting in sustained disability; reductions in quality of life; a decline in work productivity; and considerable costs to the individual, family, and society. ${ }^{3-6}$ Given the typical early age of MS onset, a profound burden of this disease is borne by patients and their families over many years.

Managing MS requires both pharmacologic and nonpharmacologic (e.g., physical therapy, occupational therapy, medical devices, and counseling) interventions to control symptoms and delay disease progression and accumulation of disability. Disease-modifying therapies (DMTs) are a core component in the pharmacologic management of MS. Of the DMTs, interferon beta (IFN $\beta$ ) formulations and glatiramer acetate (GA) have generally been regarded as the mainstay of first-line treatment in patients experiencing a first neurologic episode (known as clinically isolated syndrome [CIS]) and in those with relapsingremitting MS (RRMS). ${ }^{7}$ These immunomodulatory first-line DMTs delay conversion to clinically definite MS (CDMS) in 